\title{
Flawed and Fine? The Statue of Hel in the Museo Egizio, Turin (Cat. 7352)
}

\section{Federico Poole}

The article is a study of a seated female statue held in the Museo Egizio in Turin (Cat. 7352), so far mentioned in scholarly literature only in passing. It depicts a woman named Hel, whose involvement in cult activity is emphasized by the menat collar she holds and by references to music-making in one of the two texts inscribed on the pedestal. The sculpture, acquired by the museum in 1824 with the Drovetti collection, dates from the Nineteenth Dynasty and originates in all likelihood from Saqqara. While it belongs squarely within a well-defined tradition of New Kingdom elite sculpture, it displays some apparently unique peculiarities, which raise some questions of interpretation.

$$
\begin{aligned}
& \text { ملخص البحث: } \\
& \text { تضم المقالة در اسة حول تمثال أنثى جالسة و محفوظ في المتحف المصري في تورينو (Cat. 7352) ، لم يرد ذكره حتى الآن } \\
& \text { في الدراسات العلمية إلا بشكل عابر. يُصوِر امر أة تُدعى "هيل"، نعلم أنها كانت نتشارك في نشاطات دينية و ذلك من خلال }
\end{aligned}
$$

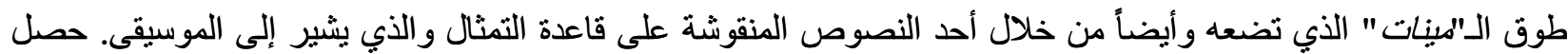

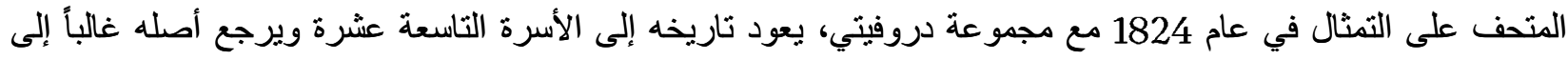

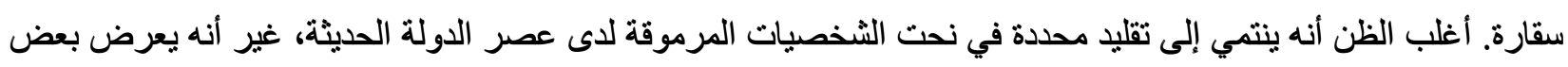

$$
\begin{aligned}
& \text { الخصائص الفريدة والتي تثير بعض الأسئلة حول تفسير ها. }
\end{aligned}
$$

\section{Introduction}

The Museo Egizio in Turin holds a somewhat smaller than life-size limestone statue $(112 \mathrm{~cm}$ tall) inscribed for a woman named Hel (Hnr) (Fig. 1). It depicts her seated on a stool, on a thin cushion, holding a menat collar in her right hand and a lotus flower in her left. She wears a tripartite wig topped by a lotus flower and surrounded by an ornamental covering indicated by a zone left plain. Her long dress reaches down to her ankles. Her feet are bare. On the high pedestal are two hieroglyphic inscriptions running around it in opposite directions in a single line. The statue leans against a backward-inclined back-pillar. The sculpture has made appearances in several of the Museo Egizio's books for the general public, ${ }^{1}$ and is cited in passing in academic literature, ${ }^{2}$ but it is studied in detail here for the first time. ${ }^{3}$ It belongs to what is known as the "Vecchio Fondo" (Early Acquisitions) of the Museo Egizio, which encompasses the objects acquired before the publication of - and hence included in - the late-nineteenth-century general catalogue of the museum. ${ }^{4}$ While most of these objects come from the collection purchased in 1824 from the French consul Bernardino Drovetti, the "Vecchio Fondo" also includes many Egyptian artifacts already in the King of Sardinia's collection before that date, as well as a significant number of objects acquired subsequently..$^{5}$ Our statue, however, must belong to the Drovetti lot. Evidence of this can be found in the inventory of the antiquities offered for sale by the French consul, which was given to Count Carlo Vidua while he was lobbying to persuade King Carlo Felice of Savoy to buy the collection. Here we read the following entry: 


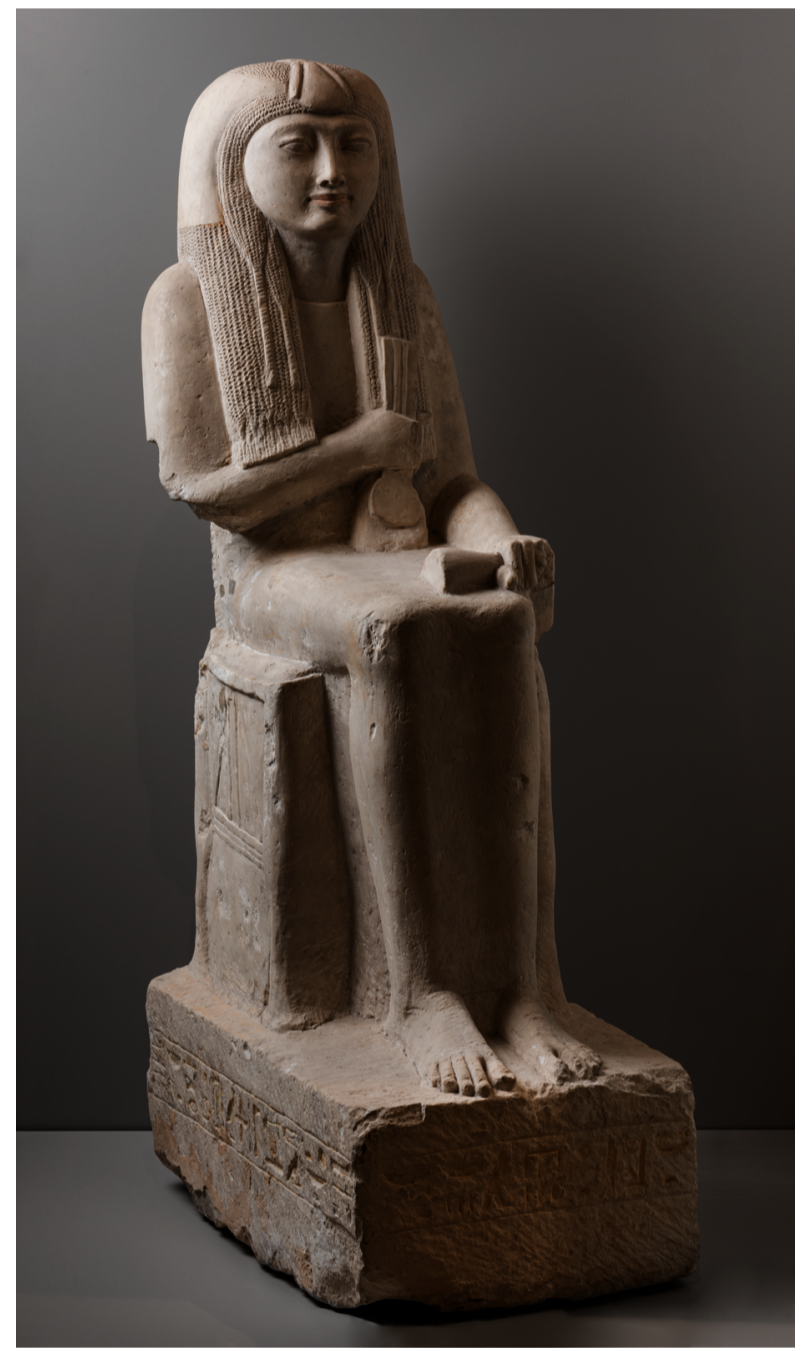

Fig. 1: Turin Cat. 7352. Photo: Nicola Dell'Aquila and Federico Taverni/Museo Egizio.

*96. Statue en pierre calcaire, assise sur piédestal ; 112 c., une bande orizontale [sic] d'hiéroglyphes faisant le tour du piédestal. ${ }^{6}$

The description is concise, but sufficient for a more than probable identification. There is no other limestone seated statue in the Turin museum of this height with a line of hieroglyphs running around the pedestal (actually only around the front and sides); nor, conversely, is any other sculpture meeting this description mentioned in the records of the pre- or post-Drovetti acquisitions in the "Vecchio Fondo".

\section{Description}

The statue (Fig. 2) is carved out of fine white limestone. It is $112 \mathrm{~cm}$ tall, 92 without the pedestal. The latter's dimensions are: height ca. $20 \mathrm{~cm}$, width 34 $\mathrm{cm}$, depth $55 \mathrm{~cm}$.

The right lappet of the wig reaches down to the right forearm, curving slightly forward as it comes to rest upon it, and is thus shorter than the left lappet. Its lower edge is slanted to match the upward slant of the forearm. The breasts are not rendered, being concealed by the arm and wig. The lotus flower spanning from the back of the head to the forehead is carved in relief, and left plain except for two deep grooves along the edges of the corolla (Fig. 3). Its stem was painted in red, the color being still preserved on its lower end, towards the back of the head (Fig. 4).

The hair of the wig, carved in detail, is arranged in tresses whose ends are tied in short thin braids. Four shorter locks of hair, gathered in as many longer and thicker braids, frame the face and throat, two on either side. Small traces of black paint on the wig suggest that it was wholly painted in this color. Much of the surface of the wig was left plain to depict an ornament - most likely an elaborate floral wreath that appears to be tied at the back of the head. Significant remnants of yellow paint, probably the original color, survive at the back of this feature, with further faint traces along the sides. A partly preserved red line runs along the top of its back left edge (Fig. 4). The wide face forms a rather rounded oval (Fig. 5). The forehead is low (or the wig covers most of the forehead). The eyebrow ridges are sharply defined, the eyes almond-shaped, the lids carefully rendered. There is no hint of either eyebrows or cosmetic lines (although these may have been added in paint). The flattened crest of the straight and rather long nose is continuous with the arch of the brow ridges. The cheeks are full and the cheekbones barely hinted at. Both the philtrum and the nasolabial furrows on either side of the mouth are rendered by slight depressions. The lips are painted red. The chin is prominent and broad. On the throat is a crease (what is known as a "Venus ring").

The right forearm is held upward across the chest, the hand clasping a menat collar's counterweight, graced by two adjacent lengthwise ridges. The bunched-together beads of the collar rest on the left thigh in a featureless lump, the sculptor having omitted to carve the individual beads. The left arm lies along the side, with the hand resting on the thigh, holding a lotus flower sculpted in half round. The woman is enveloped in a long dress, whose neck 

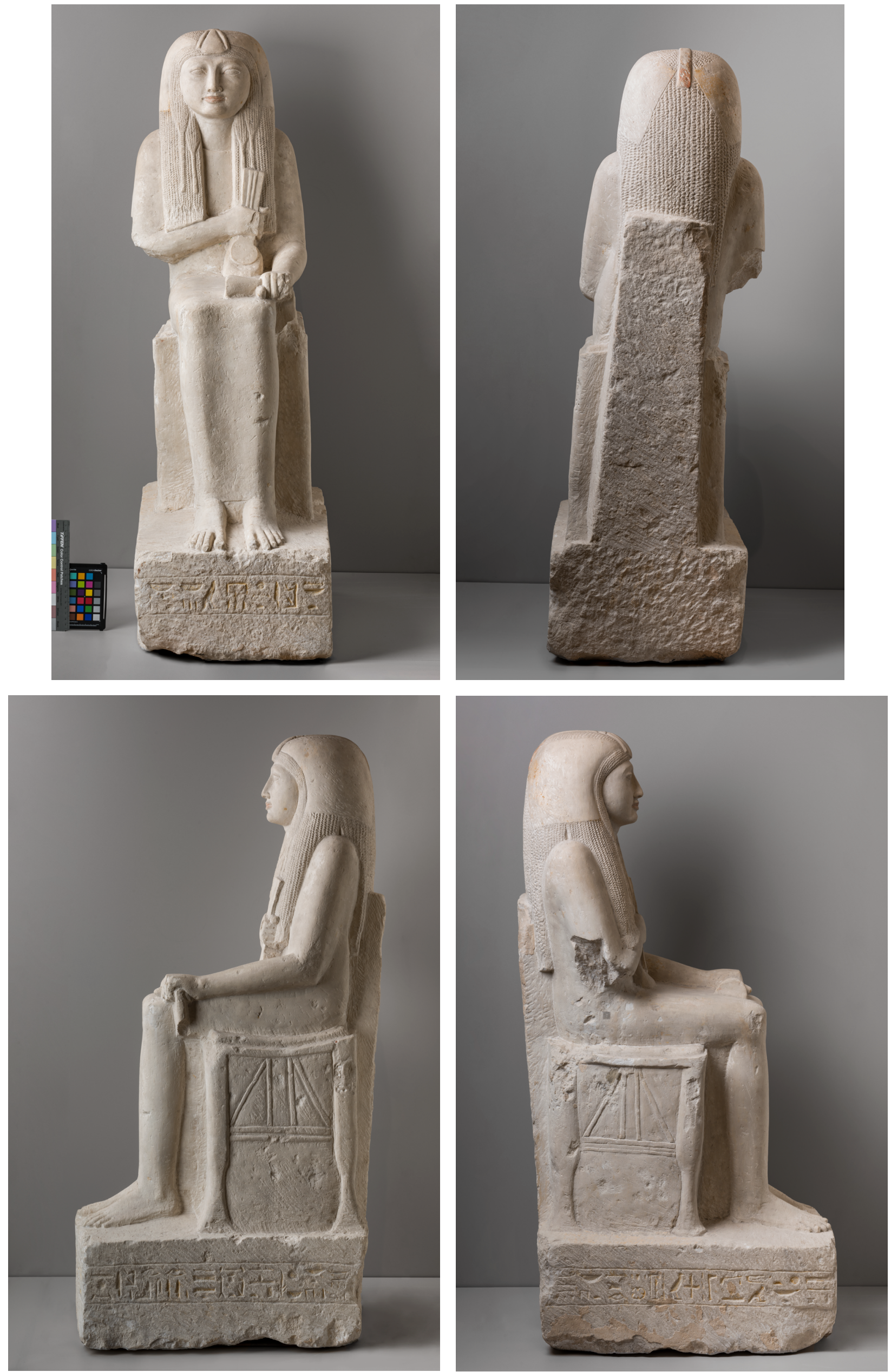

Fig. 2: Turin Cat. 7352. Photos: Nicola Dell'Aquila and Federico Taverni/Museo Egizio. 


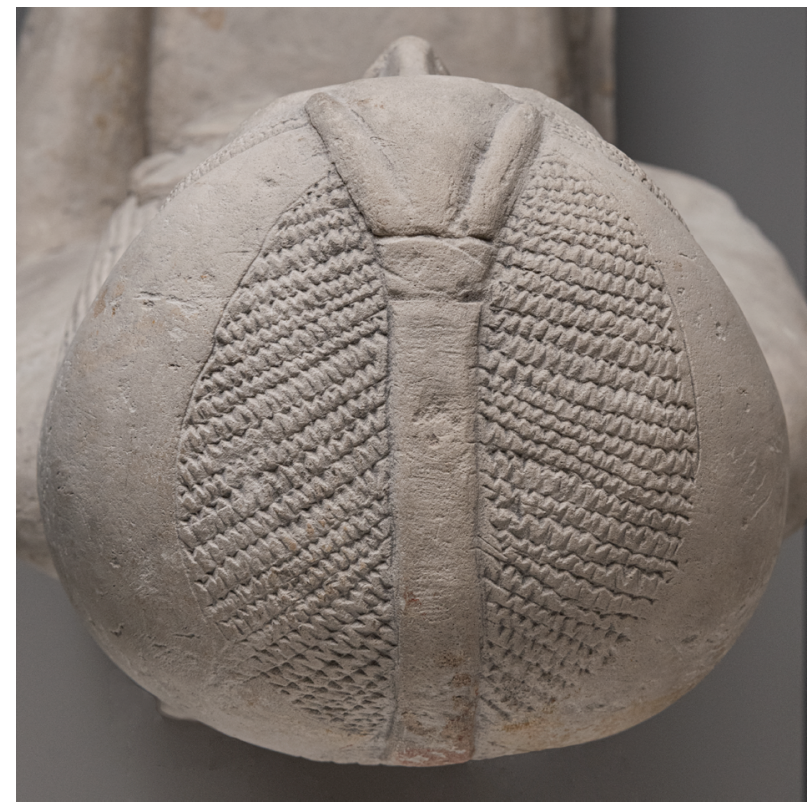

Fig. 3: Turin Cat. 7352, detail. Photo: Nicola Dell'Aquila and Federico Taverni/Museo Egizio.

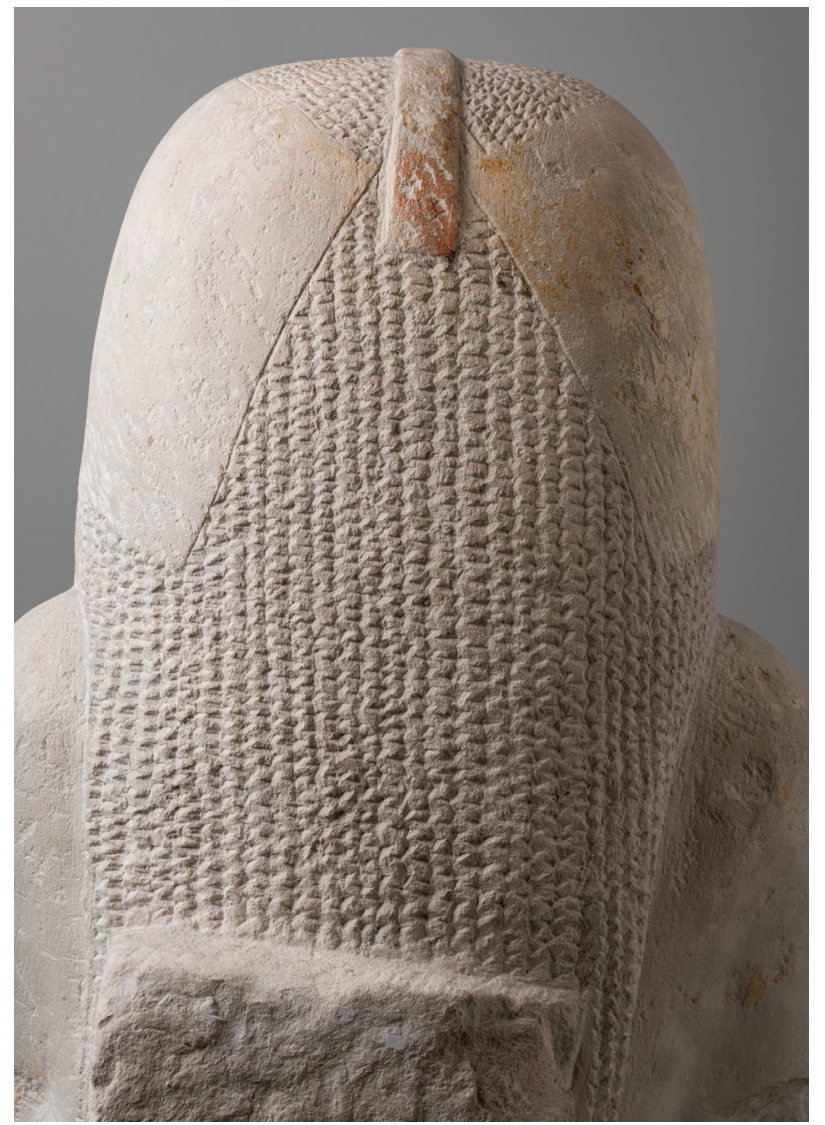

Fig. 4: Turin Cat. 7352, detail. Photo: Nicola Dell'Aquila and Federico Taverni/Museo Egizio.

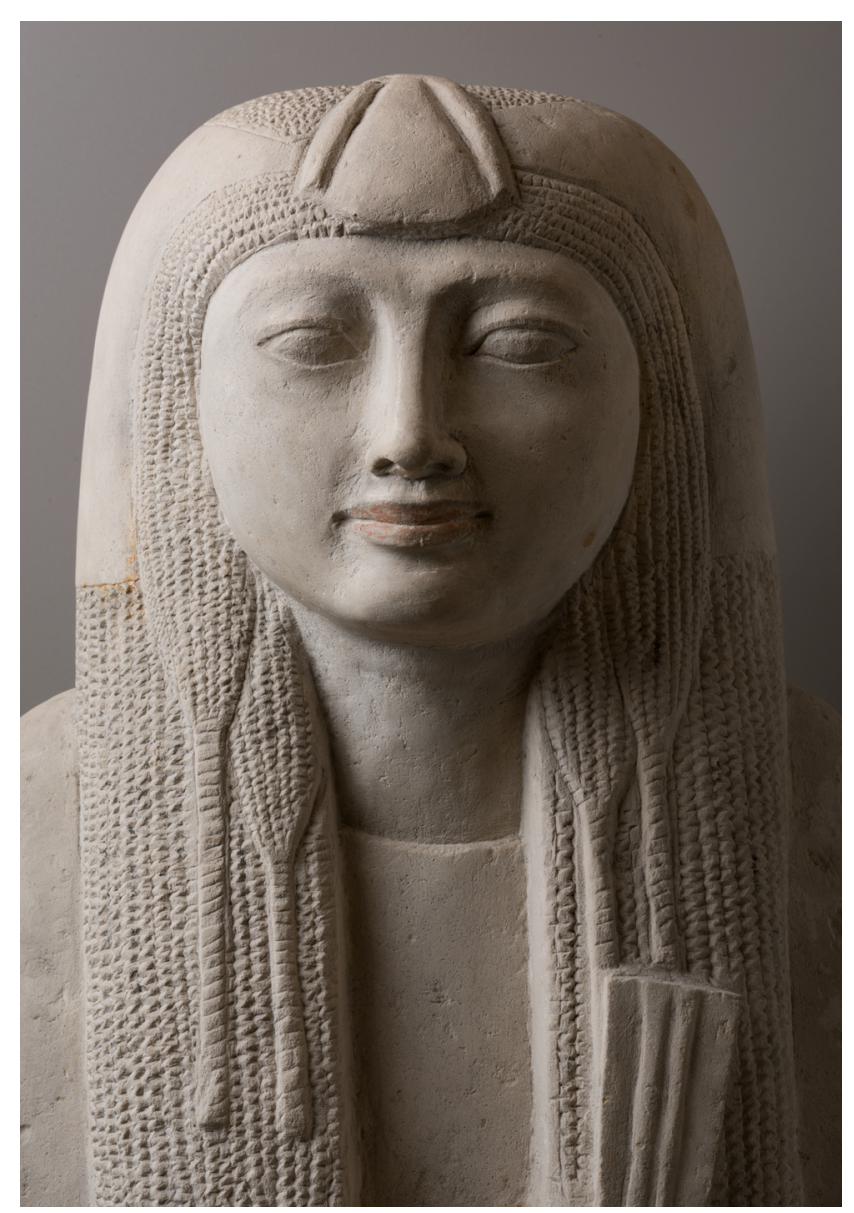

Fig. 5: Turin Cat. 7352, detail. Photo: Nicola Dell'Aquila and Federico Taverni/Museo Egizio. 


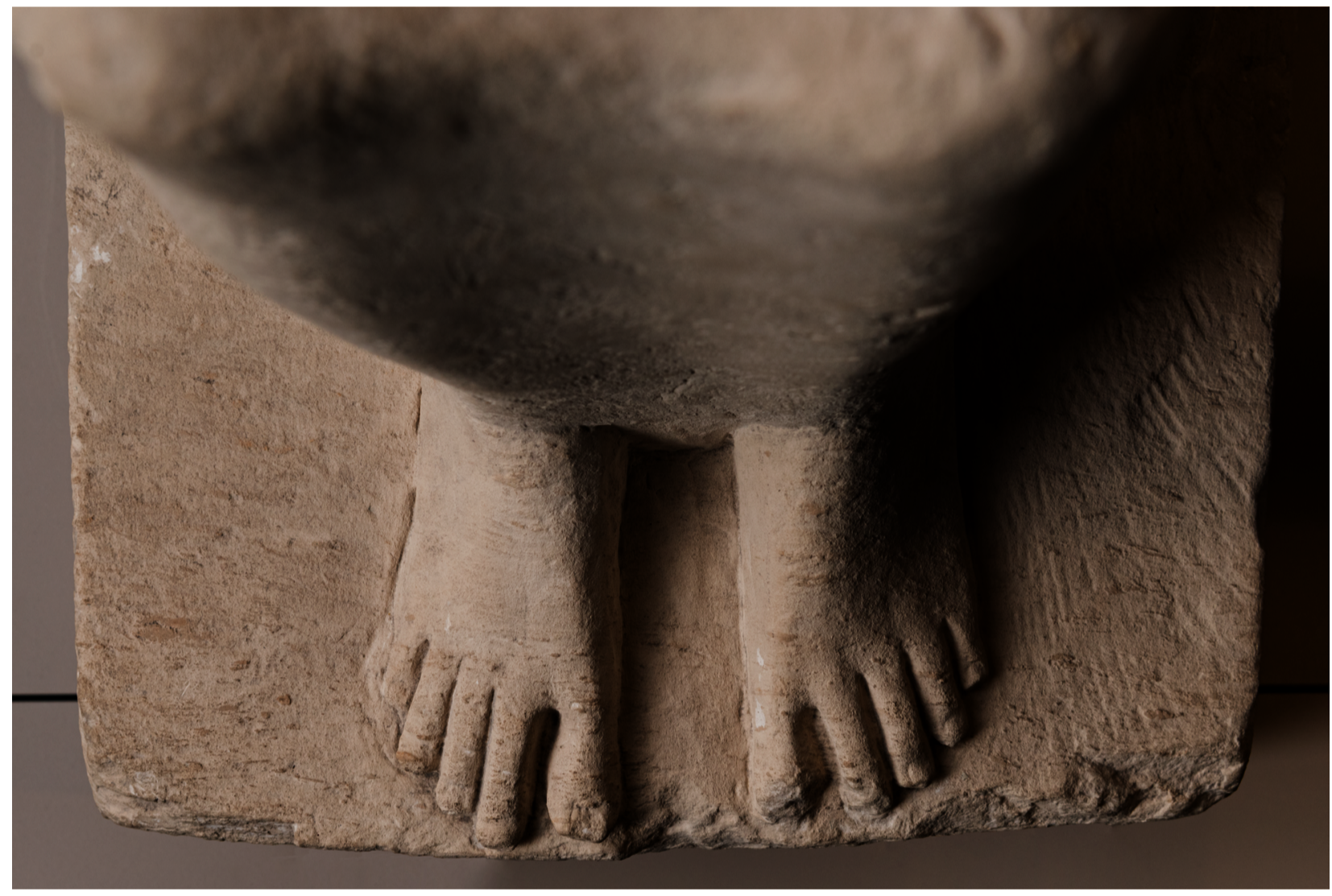

Fig. 6: Turin Cat. 7352, detail. Photo: Nicola Dell'Aquila and Federico Taverni/Museo Egizio.

and hem only are rendered, the surface having otherwise been left plain. A slight concavity between the knees and shins gives a sense of the volume of the legs underneath the dress. On the sides, the profile of the lower thighs and calves is set off by recessing the "negative space" between them and the seat.

The dress descends vertically to the feet. Its hem is depicted sculpturally only between the ankles, again by (very slightly) recessing the "negative space" beneath it. The feet are bare, with distinguished toenails and malleoli (Fig. 6).

The woman sits on a thin cushion. The stool has a concave seat, turned legs with flared feet, double stretchers, and a bracing of single vertical and diagonal struts carved in low relief out of the "negative space" under the chair. These details are rendered only on the sides, the front being smoothed but left completely plain. A backward-slanted back-pillar rises from the pedestal, partly covering the rear lappet of the wig, which protrudes slightly on either side of it. The top of this back-pillar is carelessly cut, descending obliquely to the right.

On the high pedestal are carved two hieroglyphic inscriptions arranged in a single continuous line, beginning on the front and going in opposite directions around the sides, and framed above and below by not perfectly straight incised lines.

The surface of the pedestal (except for its back, which was left rough) and that of the back-pillar are scored with long chisel marks running downward from left to right. Rather than being the vestiges of a last roughing out, they appear to have been made to ensure the adherence of a layer of pinkish plaster, remnants of which can still be seen along the (proper) right edge of the back-pillar, near the top (Fig. 4), and the (proper) right side of the pedestal; on the latter, it extends to, but never overlaps, the hieroglyphs (Fig. 11). Inside the hieroglyphs and the framing lines of the inscription, instead, are substantial vestiges of a different painted plaster, of an ochre-yellow color. The hieroglyphs thus appear to have been carved in the pedestal after it had been plastered, and then filled in with new plaster and painted yellow. The loss of the plaster the inscription was carved in accounts for a certain roughness of the hieroglyphs (see the section "Inscription" below), which may have been carved shallowly in the plaster without reaching down to the underly- 


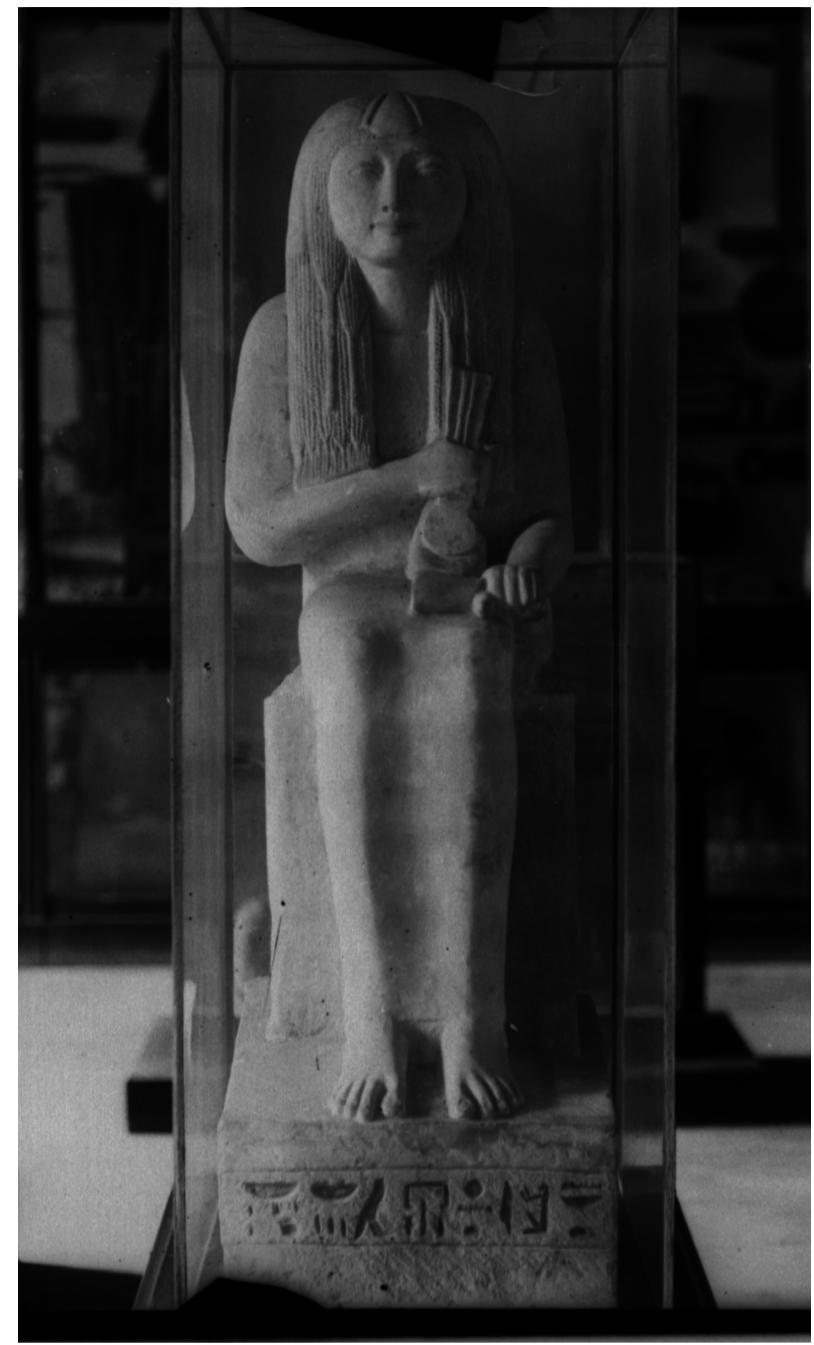

Fig. 7: Photograph of Turin Cat. 7352 taken by W.M.F. Petrie in 1893. ๑Griffith Institute, University of Oxford.

ing stone. This is confirmed by a photograph of the statue taken by Petrie in $1893,{ }^{7}$ where the plaster is better preserved and the hieroglyphs consequently appear deeper, and their outlines sharper (Fig. 7). Finally, yellow remnants of plaster can be seen here and there on the whole sculpture, notably on the left cheek; on the left side of the head ornament (the part of the wig left plain); on the back of the right upper arm; on the left forearm and hand; on the lap next to the left forearm (Fig. 8); and on the top of the pedestal to the (viewer's) left of the chair (Fig. 9).

\section{Condition}

The most serious loss suffered by the statue, inhibiting full appreciation of its original appearance, is that of its plaster and paint, which have vanished, except where indicated in the above description. The loss of the plaster, as we have seen, has resulted in the erosion of the inscription. Apart from that, the

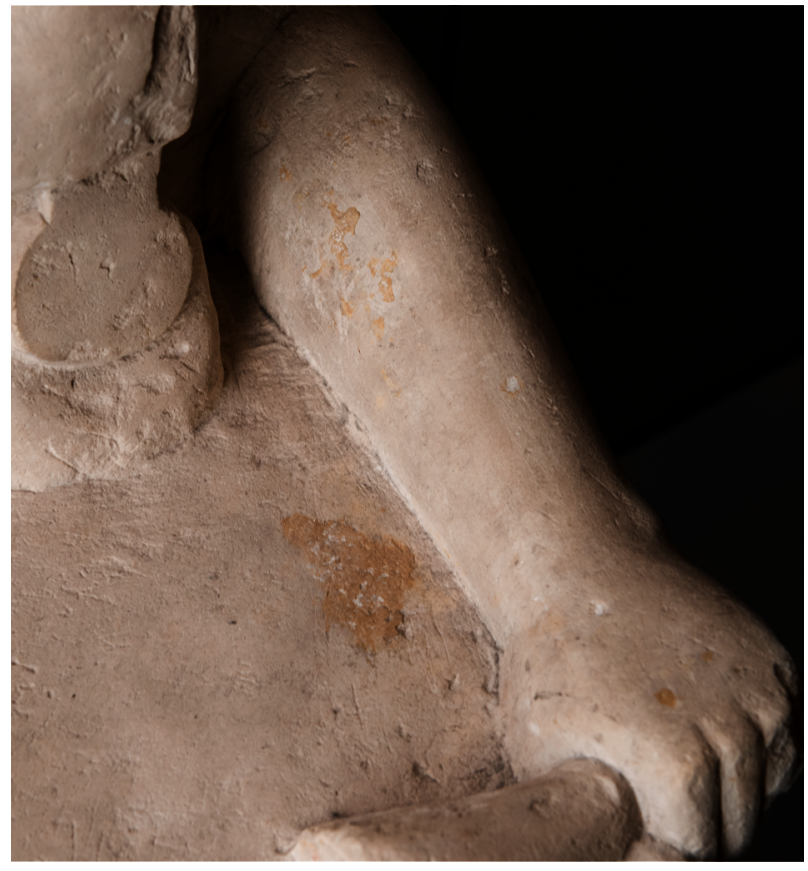

Fig. 8: Turin Cat. 7352, detail. Photo: Nicola Dell'Aquila and Federico Taverni/Museo Egizio.

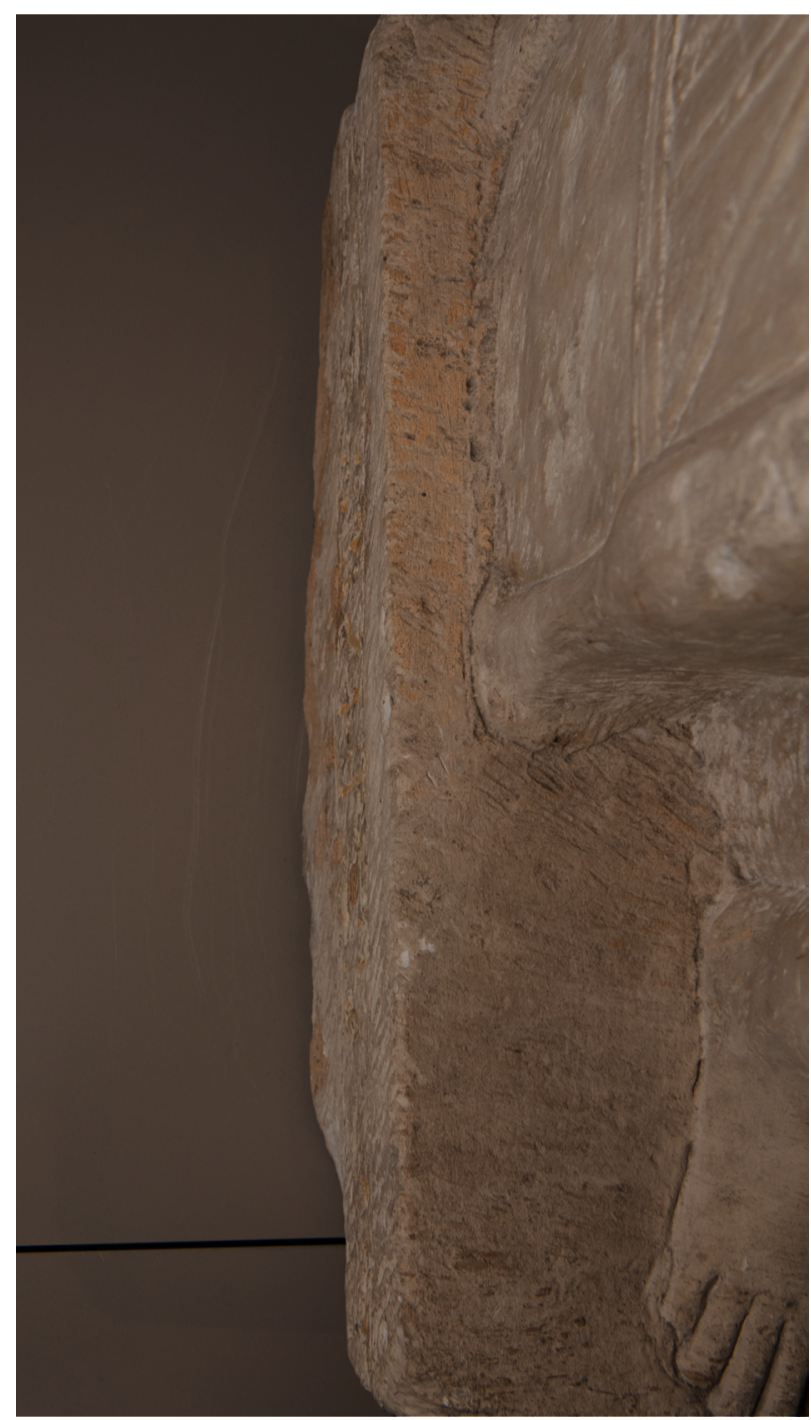

Fig. 9: Turin Cat. 7352, detail. Photo: Nicola Dell'Aquila and Federico Taverni/Museo Egizio. 
sculpture is relatively well preserved, the most evident damage being to the right elbow, the hands, the stem of the lotus flower alongside the thigh, the chair, the toenails, the back pillar, and the pedestal with the last few signs of the inscription on either side. Minor dents, abrasions, or scratches can be seen in a number of places.

There is a small dark-gray square patch on the right hip, below the elbow, evidently left by conservators to serve as a control after a thorough cleaning, carried out in $1989^{8}$ (cf. Fig. 10, taken twenty years earlier).

Petrie's 1893 photograph (Fig. 7) shows the statue in a restored state, with all the main breakages (right elbow, hands, left shin, toes, base, chair, pedestal) repaired in stucco. Most of these modern restorations are no longer present in the 1969 picture (Fig. 10). Furthermore, examination with a UV-torch ${ }^{9}$ revealed traces of extraneous material, presumably remnants of the restoration plaster, on the fracture surface at the right elbow.

\section{Inscription}

The two texts beginning on the front of the pedestal and continuing in opposite directions on either side (Figs. 11, 12) are almost completely preserved, except for a lacuna at the end of both. As noted above, some details of the signs appear to have been carved superficially in the stucco without reaching down to the stone, and to have hence been lost when the stucco fell off (cf. Fig. 7), e.g., the central element in

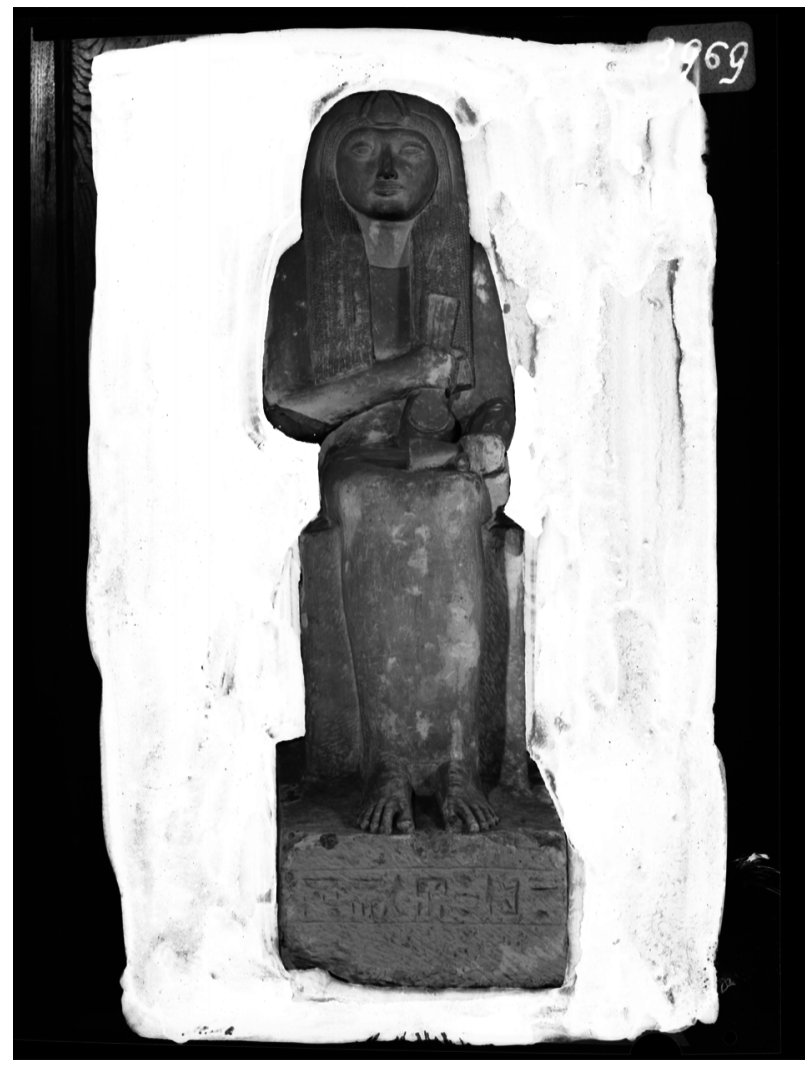

Fig. 10: Turin Cat. 7352 in 1969. Photo archive of the Museo Egizio, Turin, negative B3969. the door-bolt glyph (the $z$-sign, Gardiner O34) in the word š̌š.t on the (viewer's) right side of the pedestal. The arrangement of the two texts is unusually asymmetrical, since the group pr.t-hrw at the beginning of the right-to-left text is positioned in the middle of the front of the pedestal, leaving less than half of the available space to the left-to-right text.

Both texts were transcribed and partly translated in a Zettel for the Wörterbuch (Fig. 13). ${ }^{10}$

\section{Text 1 (Fig. 11):}

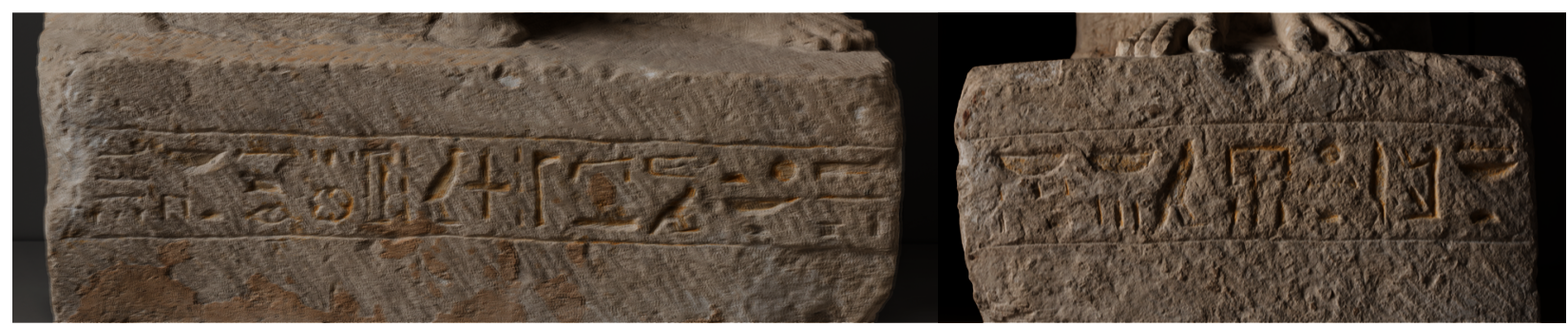

Fig. 11: Turin Cat. 7352, inscription, Text 1. Photo: Nicola Dell'Aquila and Federico Taverni/Museo Egizio.

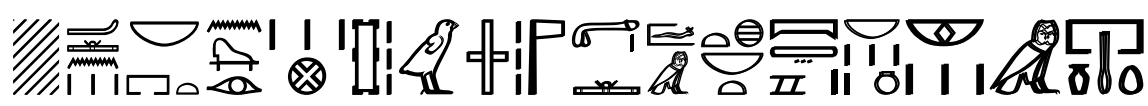

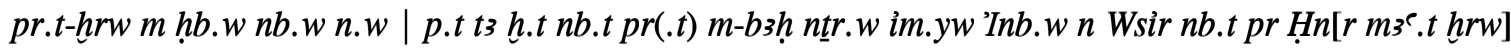


"Invocation offerings in all the festivals ${ }^{\mathrm{a}}$ of $\mid$ the sky and the earth ${ }^{\mathrm{b}}$, everything that comes forth" before the gods who are in Memphis, for the Osiris, the mistress of the house Held, [justified]."

${ }^{\text {a }}$ The rhomb inside the $h b$ sign is not visible, but may have been shallowly carved in the stucco (cf. Petrie's 1893 photograph, Fig. 7).

b For the common formula "all the festivals of the sky and the earth", see, for example, the statue of Hapu, Turin Cat. 3061; that of Merymaat and Nefertari, Bologna KS 1813; $;^{11}$ and that of Meri and his wife, Florence $1803 .^{12}$

' The use of the hieroglyph as a cryptographic writing of $p r$, while much more common from the Late Period onward, is occasionally attested in the New Kingdom as well. The earliest examples known to me occur on monuments from the time of Amenhotep III: a stela of the chief steward Amenhotep, ${ }^{13}$ a cryptographic text in the tomb of Khaemhat (TT 57), ${ }^{14}$ and stelae Louvre $\mathrm{C} 65^{15}$ and Leiden V 93, both dedicated by the imy-hnt Paser. ${ }^{16}$ Later examples, from the time of Ramesses II, are found on one of the block statues of Roma (Roy) from the Karnak cachette (CG 42186) $)^{17}$ and in the tomb of Mes at Saqqara. ${ }^{18}$

d There is barely room enough for the sitting-woman determinative and $m_{3}{ }^{-}-h r w$; one would also expect, possibly above them, the phonogram $r$ with the stroke next to it.

\section{Text 2 (Fig. 12):}

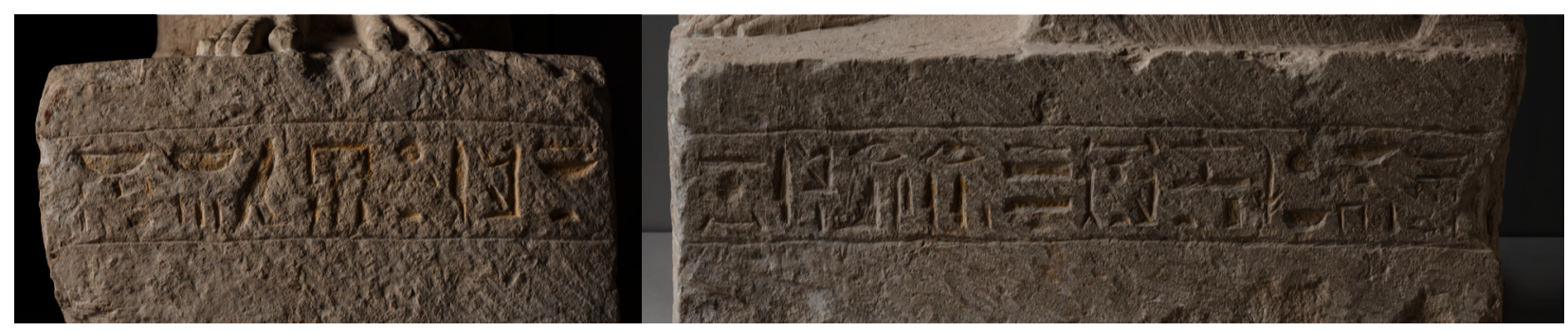

Fig. 12: Turin Cat. 7352, inscription, Text 2. Photo: Nicola Dell'Aquila and Federico Taverni/Museo Egizio.

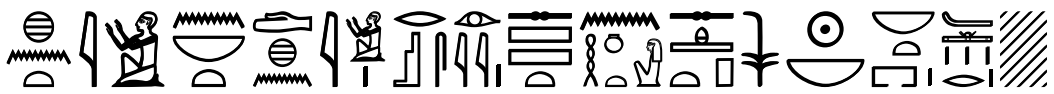

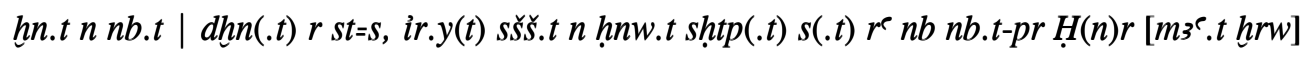

"One who makes music for the mistress and plays rhythm ${ }^{\mathrm{a}}$ at her place, one who plays the sistrum for the lady and appeases her ${ }^{\mathbf{b}}$ every day, the mistress of the house Hel ${ }^{\mathbf{c}}$, [justified] ."

a In the hand hieroglyph (Gardiner D46), the thumb is barely visible. ${ }^{19}$ Since $n b . t d h n$ is attested in Graeco-Roman times as an epithet of Hathor, ${ }^{20}$ and $n b . t$ is typically followed by a genitival extension of some sort, the alternative translation "one who makes music for the mistress of rhythm at her place" cannot be ruled out. The single strokes (Gardiner Z1) at the end of the words $d h n$ and iry are hard to explain. ${ }^{21}$

b The author of the Zettel reads the sedge-sign as ny$s w . t$, and hence translates "die das Sistrum spielt für d. Königin und den König täglich erfreut” (Fig. 13). However, the context indicates that the hnww.t is
Hathor rather than the queen, and indeed the inscription seems to be all about the statue owner's relationship with the goddess. Thus, I propose to read the sedge-sign, instead, as a writing, influenced by Late Egyptian, of the third person female dependent pronoun $s(. t) ;{ }^{22}$ still, because of the rarity of this writing in epigraphic texts, the reference to the king cannot be wholly dismissed as an alternative possibility.

' Notice the variant spelling compared to Text 1.

${ }^{d}$ There is room enough for the sitting-woman determinative and $m 3^{-}-h r w$. 


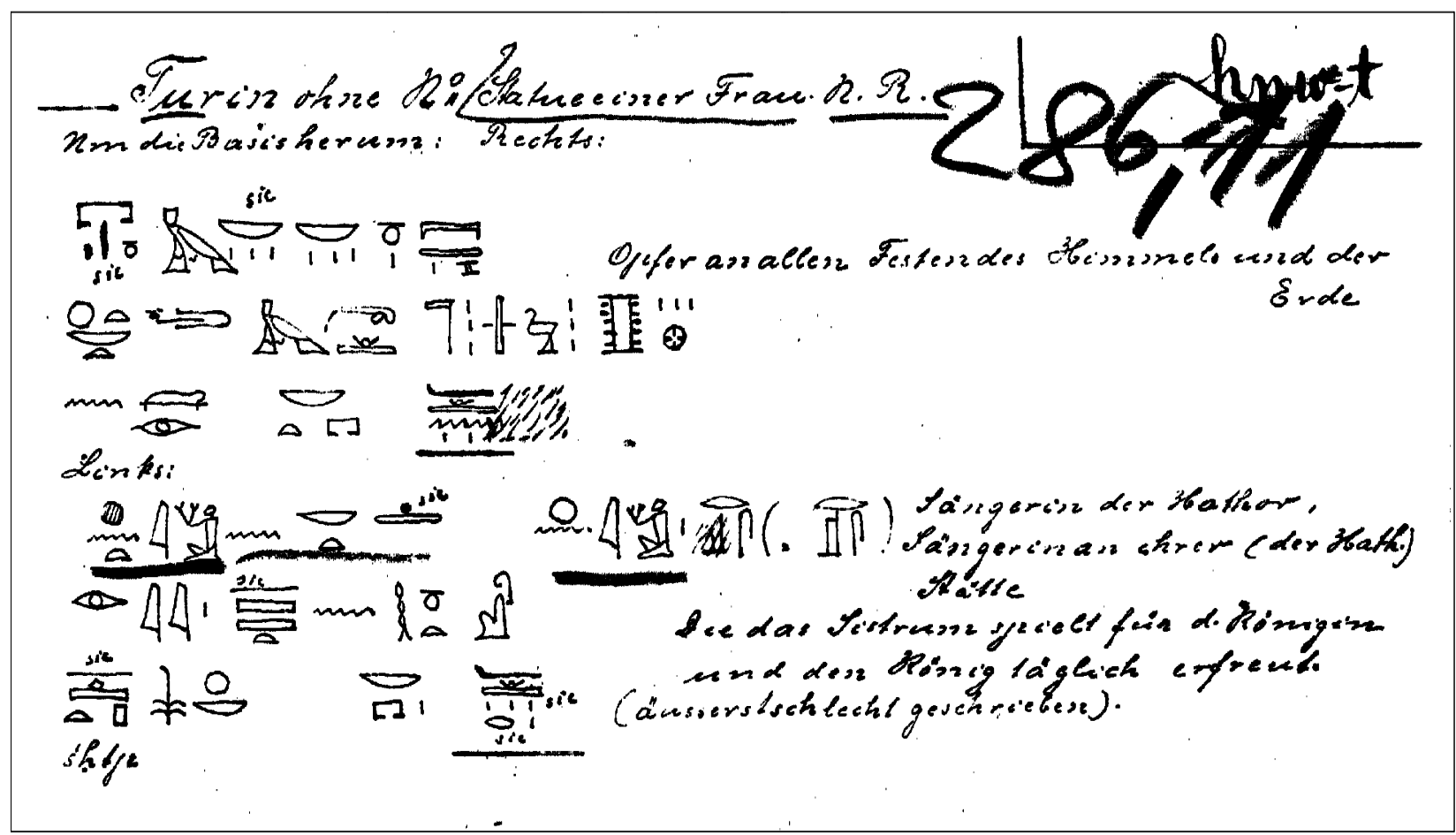

Fig. 13: Copy and translation of part of the text on the pedestal of Turin Cat. 7352 in a Zette/ for the Berlin Dictionary. BerlinBrandenburgische Akademie der Wissenschaften (BBAW), Archiv Altägyptisches Wörterbuch, DZA-Nr. 27.857.950.

Theoretically, the verbal forms in Text $\mathbf{2}$ could also be interpreted as infinitives: "Making music... playing rhythm... etc. (by) the mistress of the house..." (for the use of infinitives in a perfectly analogous context, see Fig. 15 below). This, however, would require implying an unwritten preposition in, "by". I therefore prefer to understand the verbal forms as participles serving as epithets (as does the author of the Zettel). A generic parallel can be found in the inscription on the back-pillar of the statue of Anen in Turin (Cat. 3177): dd h.t $r$ s.t iry, shtp ntr.w $m$ hrw $=f$, hm-ntr 2-nw' Imn 'nn m3'-hrw: "one who places offerings in their proper place, one who propitiates the gods with his voice, the second prophet of Amun, Anen, justified". ${ }^{23}$

The formula, for which I know no exact parallels, evokes the statue-owner's involvement, by making music and playing the sistrum, in the cult of a goddess who, while not named, is easily identifiable as Hathor. The text thus "resonates" significantly with the menat depicted in the statue's hand.

\section{Art-historical appraisal}

General considerations: The Turin statue of Hel displays features placing it squarely within a style elaborating on traditional female statue types that be- gins well into the Eighteenth Dynasty and becomes generalized from the post-Amarna period onward. ${ }^{24}$ These features include the long dress, the elaborate wig, the crease on the throat ("Venus ring"), the detailed carving of the stool, and the high back-pillar. Another Eighteenth-Dynasty innovation in female statuary is the characterization of the owner as a devotee by portraying her with a cult instrument in her hand: a menat, as in this case, or a sistrum.

Dress and figure: One of the most ubiquitous features in Hel's attire - and hence also one of the less distinctive in chronological terms - is the long (undoubtedly wrap-around, although its details are not carved) dress reaching down to the feet and thus covering the ankles (the earlier style left the ankles exposed). It appears in the reign of Tuthmosis IV in painting and in that of Amenhotep III in sculpture, ${ }^{25}$ and remains the prevalent fashion throughout the Ramesside period.

The long and slender figure is typical for female sculptures from the late Eighteenth Dynasty (compare the Leiden statues of Meryt ${ }^{26}$ ) to the Ramesside period.

Wig: Tripartite wigs with tresses ending in thin braids are commonly attested over the same time range. Sometimes, as in the statue under discussion, 

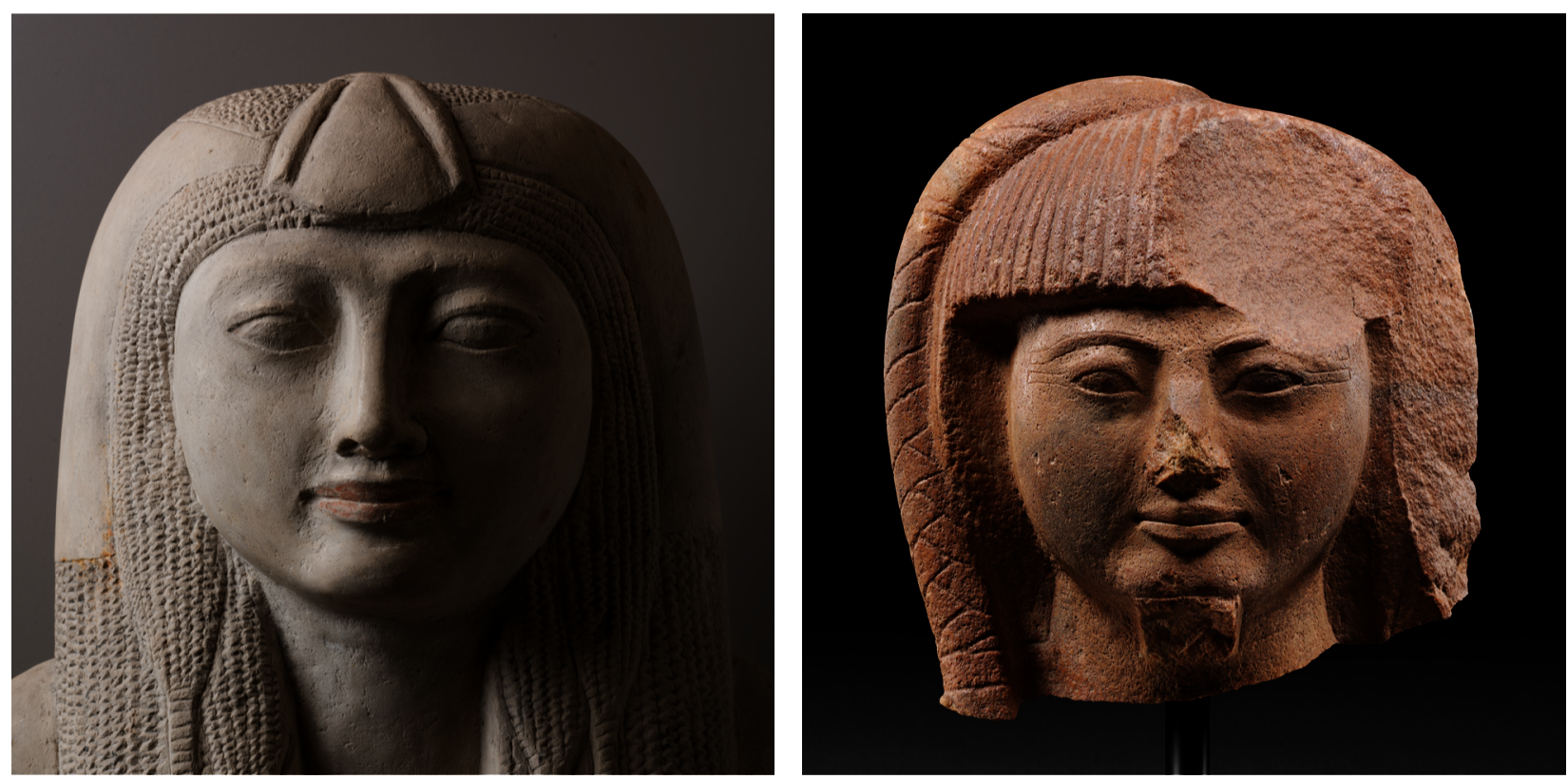

Fig. 14: Left: Turin Cat. 7352, detail. Photo: Nicola Dell'Aquila and Federico Taverni/Museo Egizio. Right: Head of a statue of Khaemwaset (?), Berlin ÄM 13460 (h. 25 cm). @Staatliche Museen zu Berlin, Ägyptisches Museum und Papyrussammlung. Photo: Sandra Steiß.

shorter tresses ("temporal locks") frame the face on either side. The earliest examples of this feature known to me are the limestone statue of Tetiseneb in Hannover, ${ }^{27}$ and a statue in the Nubian Museum in Aswan, ${ }^{28}$ both sporting single temporal locks on an earlier-type wig; their style suggests a date within the fifteenth century BC. Single temporal locks, on tripartite or enveloping wigs, occur sporadically on wooden statues dating from the time of Amenhotep III or the early years of Amenhotep IV, but only become common on stone statues in the post-Amarna period. ${ }^{29}$ The locks framing the face of the Turin statue of Hel, however, are distinctive because they are doubled, two on either side. This appears to be a much less common variant, for which I could find no further examples than those already listed by Van Walsem: ${ }^{30}$ a fragmentary statue of a sistrum-playing woman in the British Museum, ${ }^{31}$ variously dated to the Ramesside period (reigns of Ramesses II or Merenptah) ${ }^{32}$ or to the end of the Eighteenth Dynasty; ${ }^{33}$ the mummy case of Henutmehyt in the British Museum, ${ }^{34}$ forwhich the dates proposed are either late Eighteenth - early Nineteenth Dynasty, or early Ramesside (ca. 1250 $\mathrm{BC}) ;{ }^{35}$ and the lids of the outer and inner coffins of Takait (the mummy board has single locks) in Frankfurt, for which an early Ramesside date has also been proposed. $^{36}$

Another distinctive trait of our statue's wig is the right lappet extending to the right forearm and coming to rest upon it, with its lower edge matching the upward slant of the right forearm. I am not aware of any exact parallel for this feature (see discussion in the "Conclusive remarks" section below).

Likewise, I was unable to find an exact counterpart for the item of apparel surrounding the top of the wig and tied at the back. The majority of the female statues cited as parallels in the present article sport a more or less elaborate floral crown (cf. Fig. 16). In one rare instance where the statue retains its original color, this crown is golden-yellow, like the surviving traces on the back of the wig ornament of the Turin statue. ${ }^{37}$ It is very likely that this is indeed a floral crown left unfinished, although its details may have been rendered in paint.

The lotus flower gracing the wig is a very common feature, but most often carved in very flat relief, which makes its relative massiveness worth remarking (compare the half-round rendering of the lotus flower held in the left hand).

Face and neck: The rounded oval of the face, horizontal almond eyes, rendering of the mouth, and wide and prominent chin are typical for the Ramesside period; among several parallels, one could cite, for example, a statue that may belong to Ramesses II's son Khaemwaset, particularly as regards the general structure and lower part of the face (Fig. 14). ${ }^{38}$ 


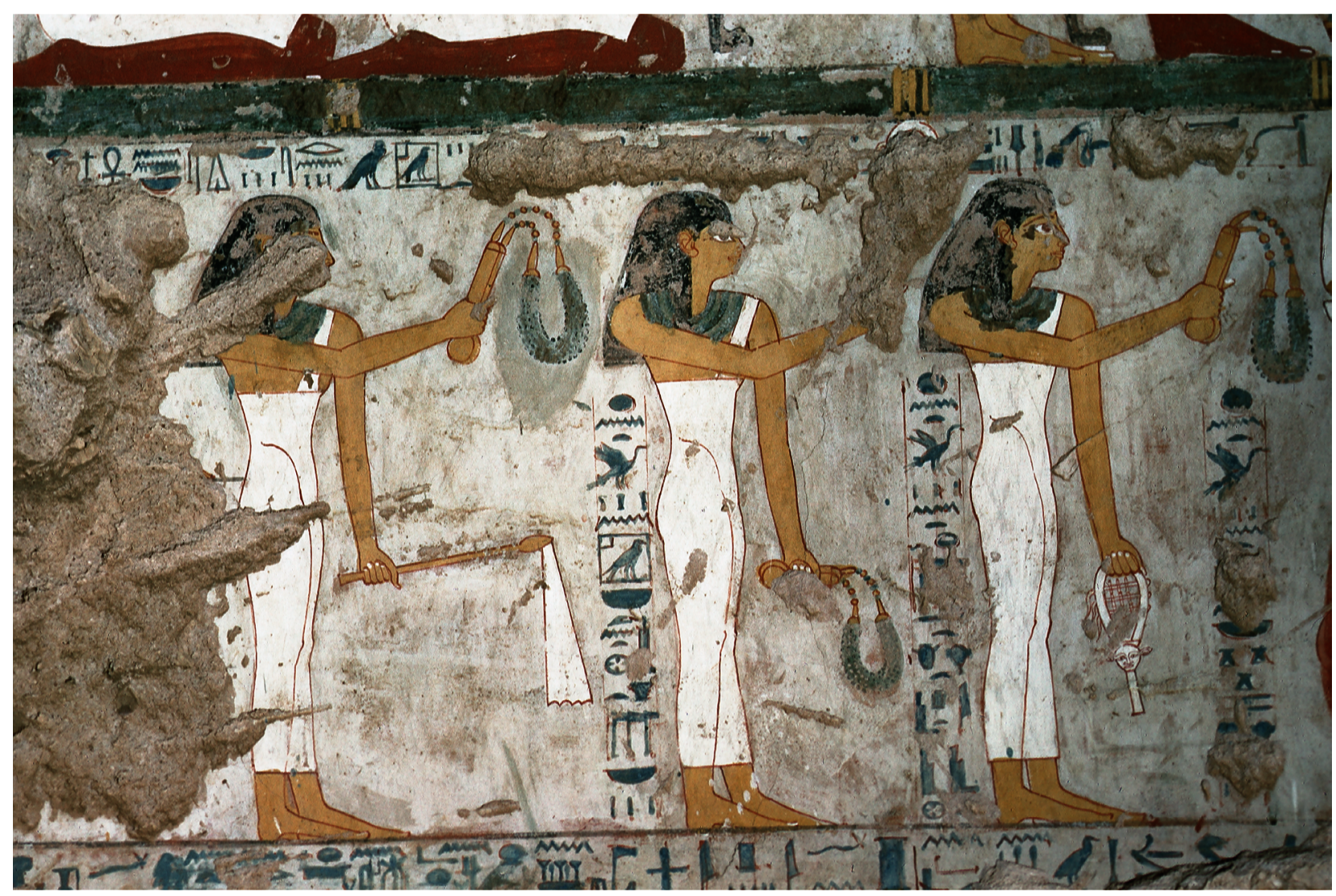

Fig. 15: Three women making music for Amun, the Ennead, and Hathor; the one in the middle is holding up a sesheshet sistrum whose upper arc is preserved. TT 82 of Amenemhat. https://www.osirisnet.net/tombes/nobles/amenemhat82/e_ amenemhat82_04.htm. @www.osirisnet.net. Photo: Bruno Sandkühler.

As to the crease on the throat ("Venus ring"), the depiction of one or more is first observed in sculpture under Amenhotep III, and regularly thereafter, down to the Ramesside period and beyond. ${ }^{39}$

Menat and lotus flower: Vandier cites Turin Cat. 7352 as the only example of his attitude type P.N.E. IV.B, designating a seated woman holding a lotus flower in her left hand resting on her thigh, and a menat collar clasped to her breast in her right hand. ${ }^{40}$ I could not find any other examples of this exact combination either.

Statues emphasizing the role of women in cult by depicting them holding a menat or sistrum are an iconographic innovation of the New Kingdom. ${ }^{41}$ Just as the menat is commonly associated with the sistrum in cultic performance ${ }^{42}$ (as it is in the Turin statue through the mention of sistrum-playing in the inscription), it is interchangeable in iconography with the sistrum. The latter is held similarly, clasped to the breast, in a number of sculptures depicting elite women that are perfect analogs to their menat-holding counterparts. The gesture is not to be understood literally, but as the equivalent of the up- held arm, detached from the body, of sistrum-playing women in reliefs and paintings; since Egyptian stone sculpture eschewed disengaged limbs, this combination of different viewing angles was an acceptable compromise. A similar representational strategy can be assumed for menat-holding statues. A scene in TT 82 of Amenemhat (Fig. 15) offers good examples of two-dimensional equivalents of the implied gestures (as well as of the interchangeability of the sistrum and menat).

The menat is held (apparently) clasped to the breast in several standing statues of elite women ranging in date from the reign of Amenhotep III to the Nineteenth Dynasty..$^{43}$ As to the specific attitude of Turin Cat. 7352 - seated with the menat to the breast and the beads resting on the lap - three parallels are known to me: the female statue in the Cairo dyad of the mistress of the house Mut[-...?] and her husband, the king's carpenter Tel (Tnr), dated to the mid-Eighteenth Dynasty; ${ }^{44}$ the statue of Meryt in Leiden (reign of Tutankhamun-Horemheb); ${ }^{45}$ and a fragmentary sculpture in the British Museum. ${ }^{46}$ However, all of these hold the menat in their left hands: Meryt be- 


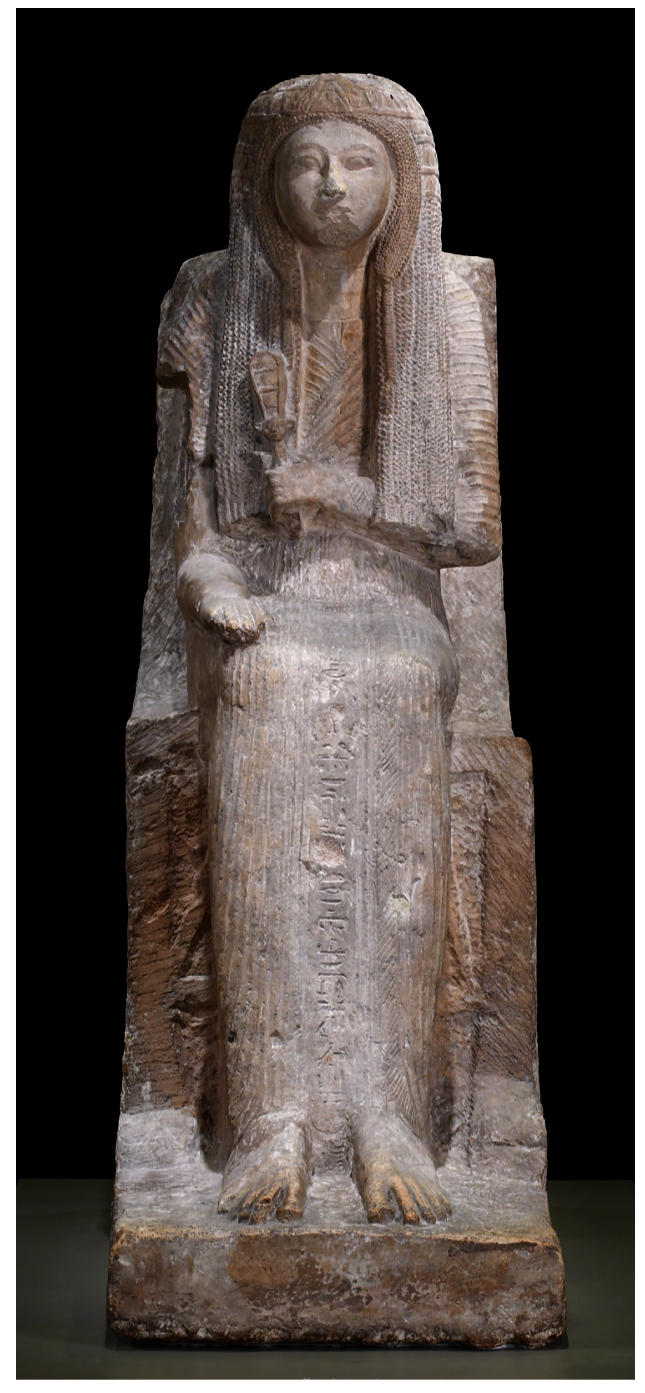

Fig. 16: Statue of Inehy, Baltimore, The Walters Art Museum, 22.106 (h. 132 cm). Photo: The Walters Art Museum. Public domain.

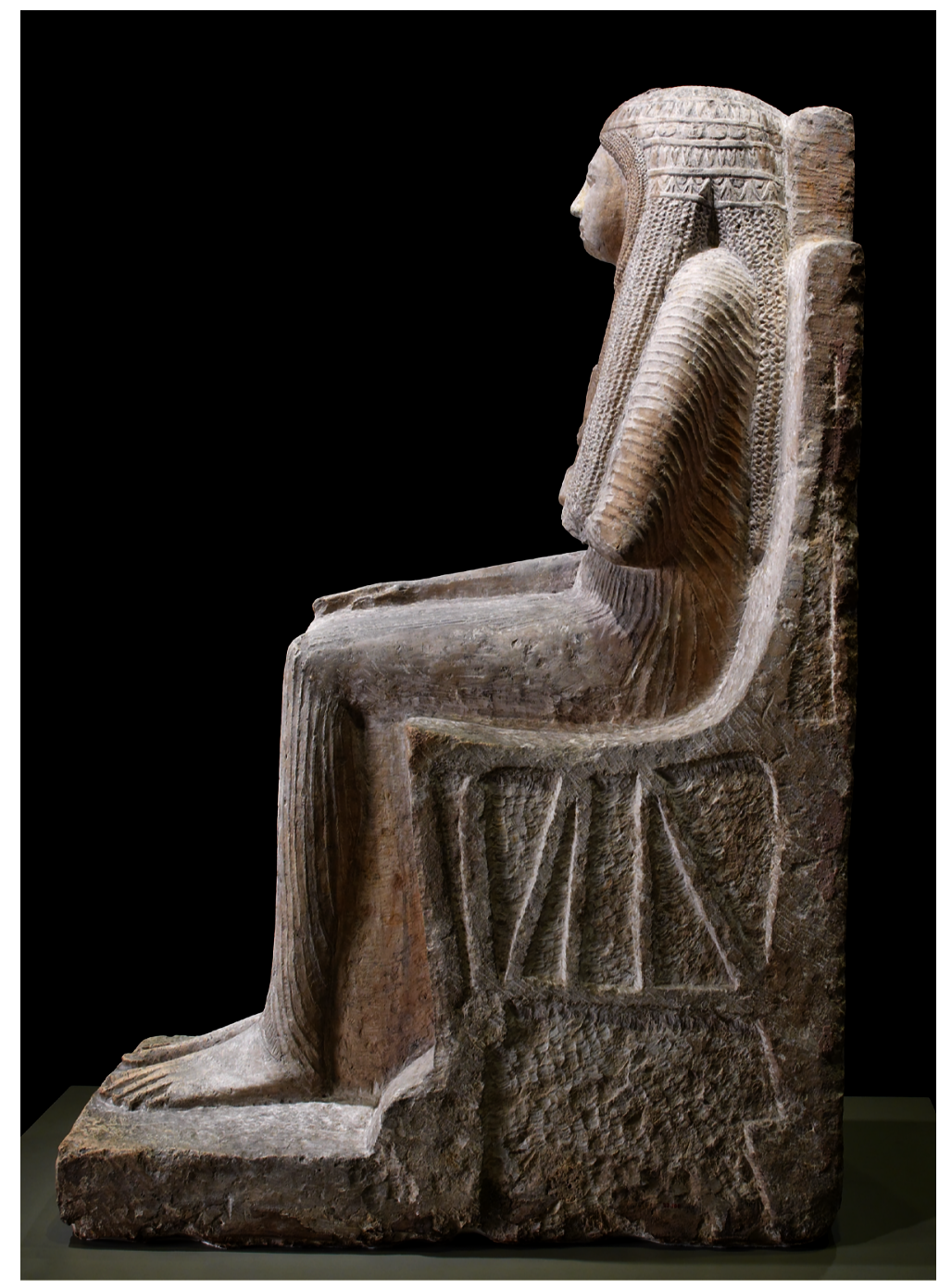

Fig. 17: Statue of Inehy, Baltimore, The Walters Art Museum, 22.106 (h. 132 cm). Photo: The Walters Art Museum. Public domain. tween the lappets of her wig, the Cairo and BM statues below the right breast. Hel, instead, holds hers with her right hand over the left lappet of her wig, exactly as the sistrum is held (except for the right/ left reversal) in the statues of Inehy, wife of the mayor of Memphis Ptahmose, in Baltimore (Fig. 16) and Tokyo. ${ }^{47}$

Turning to the lotus flower held across the thigh left completely plain by the sculptor, although some details may have been added in paint - while it is a very common feature in statuary, it is more commonly rendered in flat rather than half-round relief as here (compare the particularly thick lotus flower gracing the head). ${ }^{48}$

Seat: In the New Kingdom, chairs or stools with distinct legs begin to appear alongside the plain cubic seat starting from the reign of Amenhotep III or the Amarna period. ${ }^{49}$ The distinctive features of our statue's seat are the following: 1) it is a stool and not a chair (although the thin and backward-tilted back-pillar definitely evokes the back of a chair); 2) it has turned legs instead of lion's paw legs; 3 ) it has double stretchers on either side instead of single ones; 4) the subject sits on a cushion. All four of these features are found combined in two dyads, Berlin ÄM 6910, of the scribe Amenemope and his wife Hathor, ${ }^{50}$ and Louvre E $3516,{ }^{51}$ which thus constitute very close parallels in this regard.

The stool occurs as an alternative to the lion-legged chair in statues of both men and women, but "stools with turned legs seem to be reserved for the female sex". ${ }^{2}$ The cushion, attested in tomb decoration from about 1400 onward, is less commonly found in sculpture. ${ }^{53}$ In spite of its relative rarity, it appears to have been an appreciated iconographical feature for elite women's statues, in the light of the fact that 
the addition of a cushion was one of the modifications made to a Twelfth Dynasty statue reworked for queen Tuy, mother of Ramesses II. ${ }^{54}$

Traces of paint and plaster: The surviving traces of paint and plaster, although scanty, indicate that the statue was, or was intended to be, completely painted. The colors are standard: red for the lips, black for the hair, and red for the stem of the lotus flower; ${ }^{55}$ the head ornament retains traces of yellow paint, which is the color of the floral crown of the woman in dyad Munich Gl. W.A.F. 25 (Ney and Mutnofret). ${ }^{56}$ The color for the body would have been white. For the skin, either ochre red (cf., again, Ney and Mutnofret) or yellow. The plaster traces, yellow on the figure and pinkish on the pedestal, resemble those seen, for example, on the Baltimore and Tokyo statues of Inehy; in the former, the pinkish plaster is also used for what appears to be an ancient repair of the back slab (Fig. 17).

\section{Date}

The iconography and style of our statue place it firmly within a group of female sculptures with dates ranging from the late Eighteenth Dynasty (with the statues of Meryt in Leiden) to the Ramesside period, primarily, but not exclusively, from the Memphite area. While some of its features (detailed in the above stylistic assessment) are widespread across this group, others are less common and may help us to narrow down the date. One of them is the stool with turned legs, double stretchers, and a cushion, for which the cited Berlin statue of Amenemope and Hathor, ÄM 6910, provides a chronological benchmark in the early Ramesside period, since the man appears to have held office under Sety I and Ramesses II. ${ }^{57}$ Another distinctive feature is the wig with double temporal locks, found on coffins and statues with proposed dates to the end of the Eighteenth Dynasty or the early Ramesside period, but also to the reign of Ramesses II/Merenptah (see above, "Art historical appraisal - Wig"). Finally, as we have seen, the facial features are typically Ramesside, with a (possibly) dated parallel in a statue believed to picture Ramesses II's son Khaemwaset (Fig. 14), with the sem-priest's side lock, which he certainly sported by his father's $30^{\text {th }}$ year and until his death no earlier than the $52^{\text {nd }} .58$
Yet another element of chronological relevance is our statue's iconographic proximity (notably in the position of the menat and sistrum, respectively) to the cited Baltimore and Tokyo sistrophores of Inehy, ${ }^{59}$ wife of the mayor of Memphis Ptahmose, who flourished in the first half of the reign of Ramesses II $^{60}$ and possibly began his career under Sety I. ${ }^{61}$ While these two statues are closely patterned after the menat-holding statue of Meryt, wife of Maya, in Leiden (AST 2), ${ }^{62}$ Hel's departs from the model in several ways (double "temporal locks" instead of single ones, stool with turned feet instead of lion-legged chair, a completely different rendering of the "sleeve part" of the one-piece dress, etc.), suggesting that it may be a later elaboration (Fig. 18).

Together, all the above considerations make a strong case for a date to the earlier part of the Ramesside period, most likely within the reign of Ramesses II.

\section{Provenance}

Both the dedication to the gods of Inebu (Memphis) in the offering formula and affinities with a sculptural tradition of fine, relatively large-scale limestone statuary that is well attested in the Memphite area hardly leave any doubt as to our statue's provenance. It must have graced a tomb chapel in the New Kingdom necropolis in Saqqara - presumably standing against a wall, its back having been left rough and uninscribed. ${ }^{63}$

While the Drovetti collection is largely constituted by antiquities from the Theban area, it does include several artifacts traceable to Saqqara: notably, four alabaster jars and a model scribe's palette inscribed for Djehuty, the presumed hero of the story of the taking of Joppa, some of whose grave goods are dispersed among several European museums. ${ }^{64}$ In the inventory or "sale catalogue" of the Drovetti collection inaccurately known as the "catalogo Vidua", our statue's item number is prefixed by an asterisk, ${ }^{65}$ which designates objects acquired "depuis le mois de X ${ }^{\text {bre }} 1820$ ". At least some of the jars of Djehuty are recognizable in the "Objets en albâtre" section among items 74 through 80 , and these are also prefixed by an asterisk. ${ }^{66}$ Lilyquist argues - on other grounds - that the (lost) tomb of Djehuty must have been found at Saqqara between 1820 and $1822 .{ }^{67}$ It thus appears that Drovetti acquired a number of ob- 


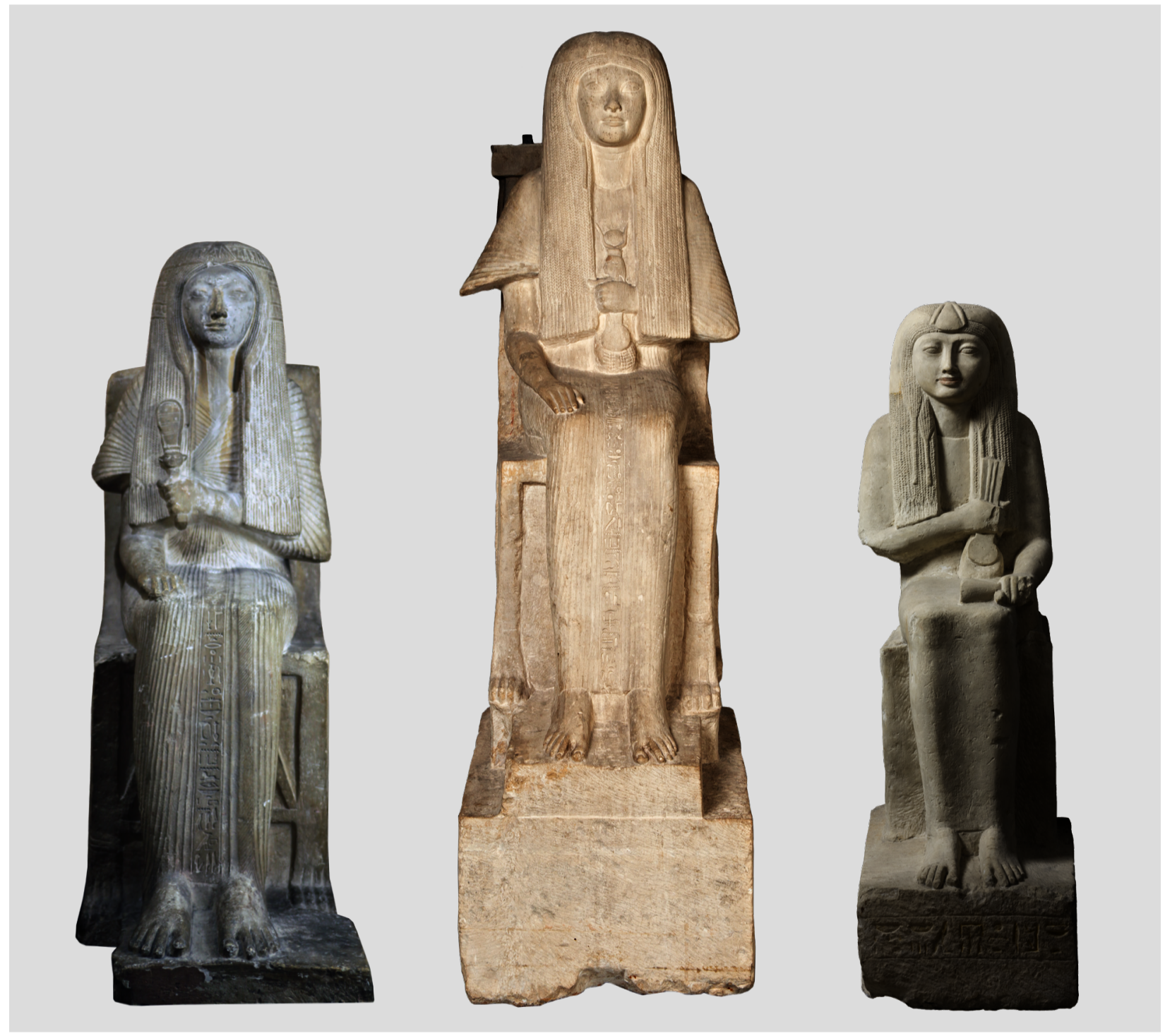

Fig. 18: From left to right:

Statue of Inehy, Matsuoka Museum of Art, inv. no. 568 (h. ca. 122 cm). @Matsuoka Museum of Art.

Statue of Meryt, Rijksmuseum van Oudheden, Leiden, AST 2 (h. 188 cm). @Rijksmuseum van Oudheden.

Statue of Hel, Museo Egizio, Turin, Cat. 7352 (h. 112 cm). Photo: Pino Dell'Aquila and Nicola Dell'Aquila/Museo Egizio.

jects from that site during those years, including the statue of Hel.

\section{The owner}

The reference to the gods of Memphis in one of the statue's inscriptions clearly identifies its owner as a member of the Memphite elite. Indeed, the sculpture fits well within a local tradition of often exquisite, more or less large-format tomb-chapel statues from the area (compare some of the parallels cited above). However, in the absence of an archaeological context, of the mention of relatives, or of a more distinctive title than "mistress of the house", any attempt at identification must necessarily be tentative. The name Hel or Hely (Hnr/Hnry, also tran- scribed as Huner[y]), ${ }^{68}$ commonly attested in the Ramesside period, is borne by a number of women commemorated on monuments from the Memphite region. ${ }^{69}$ While attempting to identify the Hel of the Turin statue with any of these would be little more than speculation, it is perhaps worth mentioning, in terms of mere possibility, that a Hely qualified as a chantress of Hathor of the Southern Sycamore (the Memphite form of the goddess) ${ }^{70}$ is featured, playing the sistrum, as the dedicator on a Memphite stela showing the High Priest of Ptah Pahemnetjer (Sety I to early reign of Ramesses $\mathrm{II}^{71}$ ) and other individuals paying homage to Osiris and Hathor of the Southern Sycamore. ${ }^{72}$ Another sistrum-wielding Hel or Hel[y], the wife of Nakhtmontu, fanbearer on the right of 
His Majesty, is depicted on a fragment of a fine relief from her husband's funerary chapel, reemployed in the Monastery of Apa Jeremias in Saqqara. ${ }^{73}$ Finally, in Tomb Bubasteion I.16, Hel is mentioned as the name of the mother of Nefertary called Tamyt, wife of Netjerwymes called Parekhnua, high steward of Memphis, overseer of the treasury and overseer of all works (reign of Ramesses II). ${ }^{74}$

\section{Flawed and fine? Conclusive remarks}

Some features of statue Turin Cat. 7352 are worth dwelling further upon.

As noted in the description, the carving of the statue was never completed. The details of the stool are only rendered on its sides, but not at all on its front, which is left plain, as is the floral wreath (?) gracing the head. The beadwork of the menat was not carved, either. The lack of "pleating"75 and a wesekh collar could also be categorized as unfinished carving. A plain dress is common in earlier New Kingdom examples, but most of the iconographic parallels cited in the present article have either a fully "pleated" dress and a collar, or at least the collar and some indication of the details of the dress (such as the "sleeve" part, the edge of the part knotted under the breast, some folds, etc.), notable exceptions being the female statues in dyads Bologna KS $1813^{76}$ and Munich Gl. W.A.F. $33 .{ }^{77}$ It is unlikely that these elements were merely rendered in paint and are now lost, as such an approach seems to be unparalleled in statuary, ${ }^{78}$ although it is attested for shabtis. ${ }^{79}$ Incomplete carving of a statue is far from unusual, and obviously did not prevent the sculpture from performing its function in the context it was intended for. It is also observable, to a lesser degree, in some of the closest parallels for the Turin statue, notably the Baltimore statue of Inehy cited above, where the lion legs of the chair, as seen in its counterpart in Tokyo, were left uncarved. ${ }^{80}$ Even in works of exceptional quality such as the Leiden statues of Maya and Meryt, some parts of the chair, menat and wig were left unfinished; in Martin's words, “[e]xamination of the three surviving statues of the tomb owners indicates that work was skimped in certain areas" ${ }^{81}$ Characterizing this incompleteness as a "flaw" is certainly an etic judgment, based not only on the application of a modern standard of thoroughness, but also on the current appearance of the statues, whose incomplete carving may have been dissimulated, to a certain extent, when they were fully plastered and painted. Still, the very fact that some sculptures are fully carved suggests that the ancient Egyptian clientele were not without expectations in this regard. A comparison between the Baltimore and the Tokyo statues of Inehy, in their different stages of completion, clearly indicates that partial carving was not something planned from the outset. The impression is that it was not unusual for artists to work under temporal constraints whose nature can only be conjectured.

Premature death of the subject certainly would have been one possible reason for urgency, also considering that statues and stelae would have been the last elements of the decoration to be installed in the tomb. On the other hand, the preparation for the building of an elite tomb could start early in the career of its owner(s) - Horemheb's first tomb at Saqqara being a well-known case in point - and the incompleteness of statues is observed frequently enough that we must assume that there were other factors at play that could induce artists to take shortcuts or leave some elements unfinished. ${ }^{82}$

Remarkably, almost all the parallels mentioned in this article are more thoroughly carved than the statue of Hel. This suggests that it stands closer to the lower end of a hypothetical acceptable range of finiteness (in emic terms).

Another noticeable trait of our statue that stands out is its pronounced lean toward the proper right. This does not depend, as I had initially assumed, on damage to the undersurface of the pedestal resulting in the loss of its perpendicularity to the vertical axis of the statue: the pedestal, measured near the front corners and near the front feet of the stool, is about the same height on either side, ca. $19.5-20 \mathrm{~cm}$, with the (proper) left side only a few millimeters higher. The figure of the woman is actually misaligned with the pedestal, and most evidently with the back-pillar, as we can verify by imaginarily extending the stem of the lotus flower at the back of the head downward in a straight line (Fig. 2). While it is common for Egyptian statues not to be perfectly vertical, the asymmetry of our statue is conspicuous enough to appear as a flaw, and is all the more striking when 
contrasted with the artist's finesse in rendering the woman's face and figure.

Other elements indicating rushed or interrupted finishing include the oblique cutting of the top of the back-pillar and the irregularity of the lines framing the inscription. A further possible instance of hasty work is the placing of the group pr.t-hrw in the exact middle of the front of the pedestal. The group is suited to occupy this position, being almost totally symmetrical and hence readable indifferently from right to left and vice versa. Its central placement, however, would only make sense if it were indeed to be read twice at the beginning of two texts going in opposite directions, which is not the case: it only belongs to the text going leftward, and its position hence causes the inscription to be uncharacteristically asymmetrical in its layout.

While incompleteness is quite commonly remarked in Egyptian statuary, there is another peculiarity of our sculpture that appears to be unique, namely, the way the right lappet of the wig extends to the forearm, coming to rest upon it and slanting downwards to match the profile of the upper edge of the forearm (Fig. 19).

The fact that no parallels for this feature are known, as far as I could verify, may be simply due to the relative smallness of the sample of statues preserved from this period. However, there are considerations that invite us to envisage another possibility.

1. The solution the sculptor came up with has the side-effect that the right lappet is shorter than the left one, as well as having a slanted lower edge as opposed to the horizontal lower edge of the left lappet. This contrasts with the typical rendering of symmetrical wigs on statues, where the lappets are of the same length and shape.

2. As noted above, our sculpture shows a remarkable iconographic proximity to the statues of Inehy in Baltimore and Tokyo and the menat-holding statue of Meryt in Leiden. One detail in which these three parallels differ significantly from the Turin statue, however, is precisely the rendering of the left lappet of the wig, which in their case overlaps the left forearm.

3. No parallel exists, at least to my knowledge, for a wig connecting to the arm as in Turin Cat. 7352.

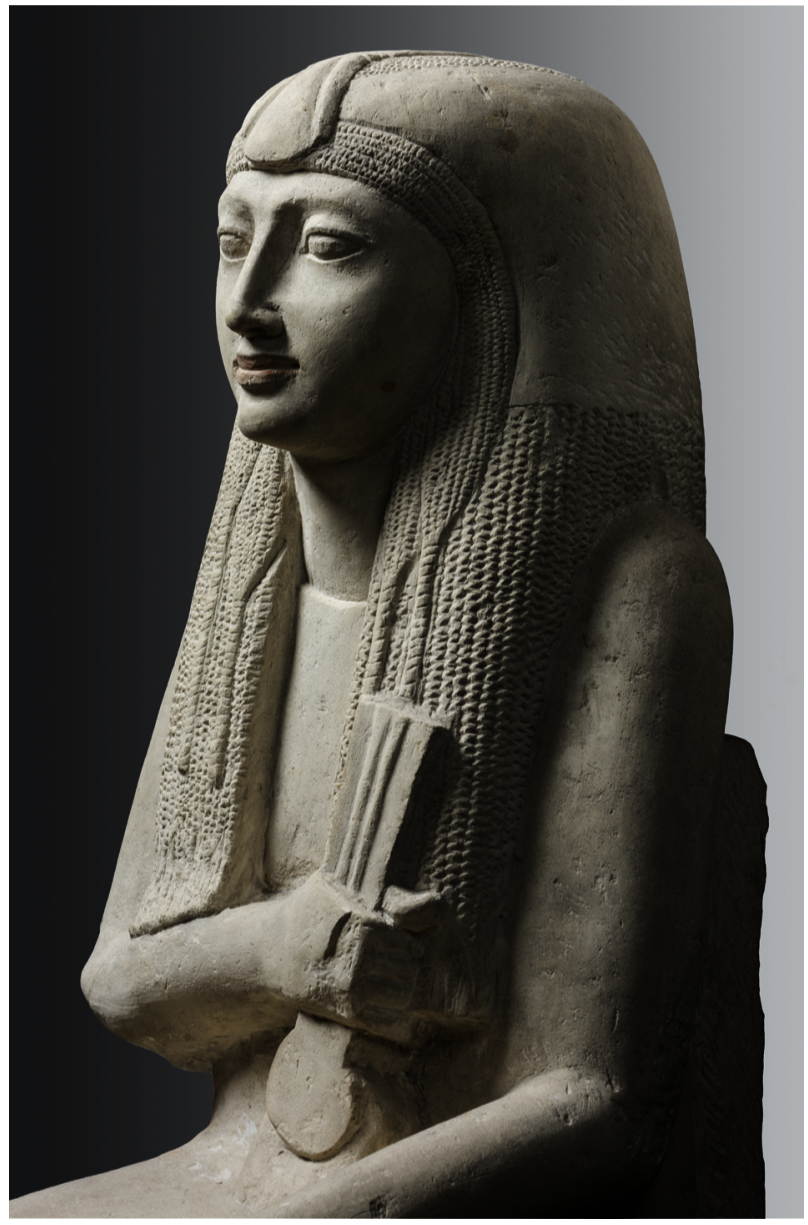

Fig. 19: Turin Cat. 7352, detail. Photo: Pino Dell'Aquila and Nicola Dell'Aquila/Museo Egizio.

4. As we have seen, our statue - notwithstanding its exquisiteness - displays evident signs of hasty workmanship.

In the light of the above, I would consider the possibility that our sculptor had been following a popular model and his plan had been indeed to carve a wig overlapping the forearm (Fig. 20). The unique solution he arrived at may have been ad hoc, the result of a change of plan in the course of his work due either to a wish to cut corners (literally, as it were) or to technical problems encountered, such as the removal of too much material where the part of the wig overlapping the arm was intended to be, i.e., not allowing for the additional depth required to sculpt this feature. ${ }^{83}$

This hypothesis provides a plausible explanation for the Turin statue's deviance from the norm; at the same time, however, it can hardly be proved. We cannot rule out that this variation on a prestigious model may have actually been planned from the outset, 

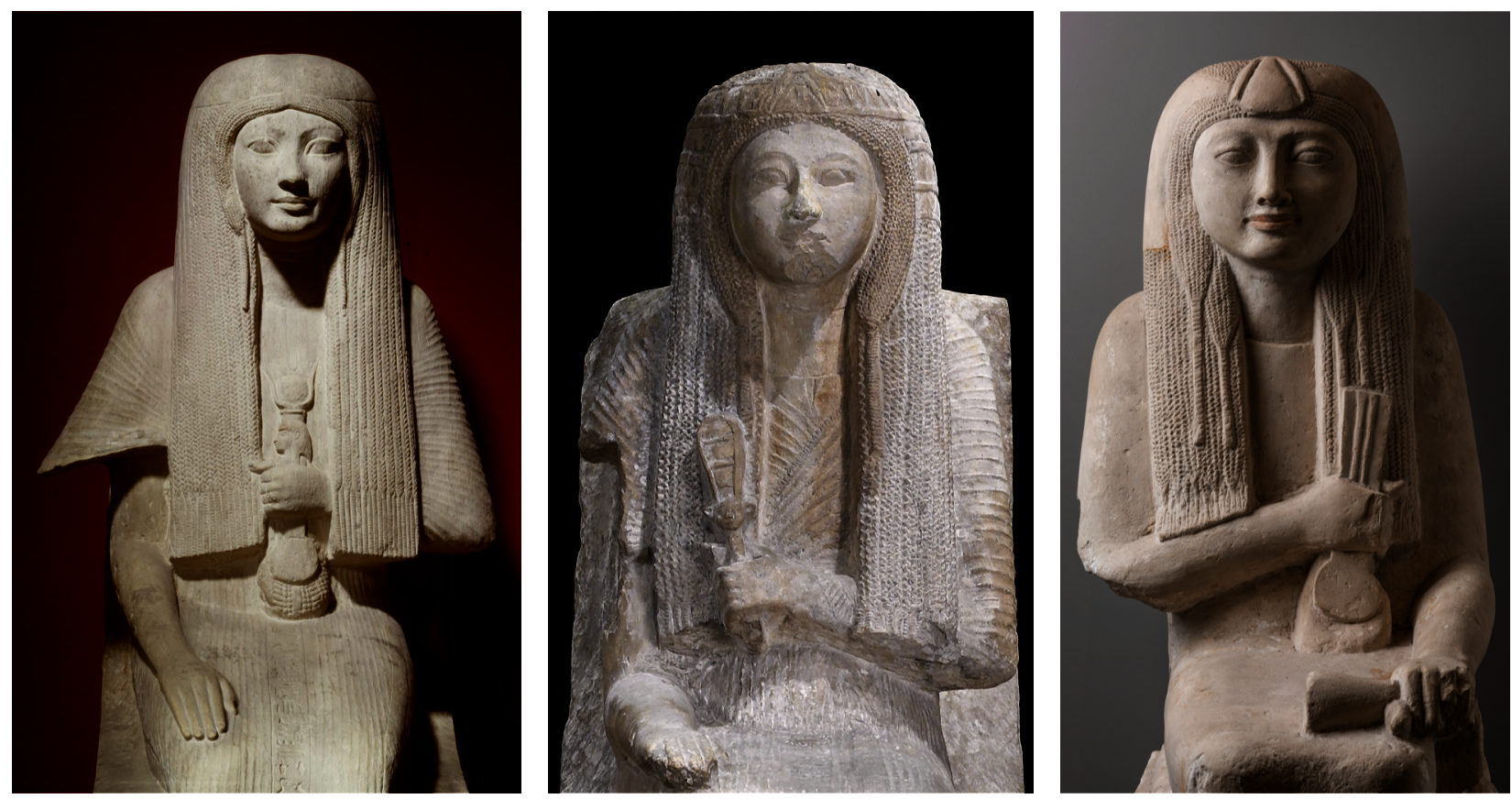

Fig. 20: From left to right:

Statue of Meryt, Rijksmuseum van Oudheden, Leiden AST 2. ๑Rijksmuseum van Oudheden.

Statue of Inehy, Baltimore, The Walters Art Museum, 22.106. Photo courtesy of The Walters Art Museum. Public domain. Statue of Hel, Turin Cat. 7352. Photo: Nicola Dell'Aquila and Federico Taverni/Museo Egizio.

and that the absence of parallels may be merely due to the accidents of preservation.

In either case, a detail of this iconographic feature appears to reflect a trend that surfaces occasionally in New Kingdom art. I am referring specifically to the way the bottom of the right lappet of the wig does not simply halt at the forearm but, as we have seen, actually comes to rest upon it and hence curls slightly forward. This kind of "realistic" notation appears here and there in the sculpture of this period, in various forms, and stands out vividly in the context of a figurative language where form habitually tends to fully coincide with function. The overall intent of our statue is to show an individual in the flower of her years, with attributes connoting her status (her apparel, the stool) and her involvement in cult (the menat), itself a status symbol. Every detail of the sculpture is carved to communicate this information, nothing less and nothing more, with one apparent exception: the forward curve of the right lappet of the wig.

Examples of stylistic devices grounded in a similar sensibility include the slight lifting to the side of some strands of the woman's wig by her right arm, raised to embrace her husband, in the Cairo dyad of Tjay and Naia; ${ }^{84}$ the way the menat collar is held with the necklace part hanging in front of the knees in the dyad of Iuny and Renenutet in the Metropolitan Museum; ${ }^{85}$ and the uniquely intertwined hands of the couple in the British Museum dyad of Horemheb and one of his wives. ${ }^{86}$ What these features have in common is that they subtly add a level of aesthetic communication with the viewer that appears not to be strictly related to the main significance of the statue as an image of the deceased with the attire and accoutrements connoting his or her social status and relationship with the gods. It is only in these individual details that form and function do not totally coincide - although all the requirements of decorum are met, such touches being mere ripples on its otherwise impassible surface. They seem to bring a touch of the contingent, of the here-and-now, within an otherwise atemporal aesthetic context. ${ }^{87}$ At the same time, there is a quirkiness about them that relates directly to the sculptor's self-expression, and in this sense we could also regard them as "mannerisms" - a definition that could be extended to include features such as the overlapping of the tips of Nut's wings, and of her hands holding ankh-signs, on the "sleeves" of 


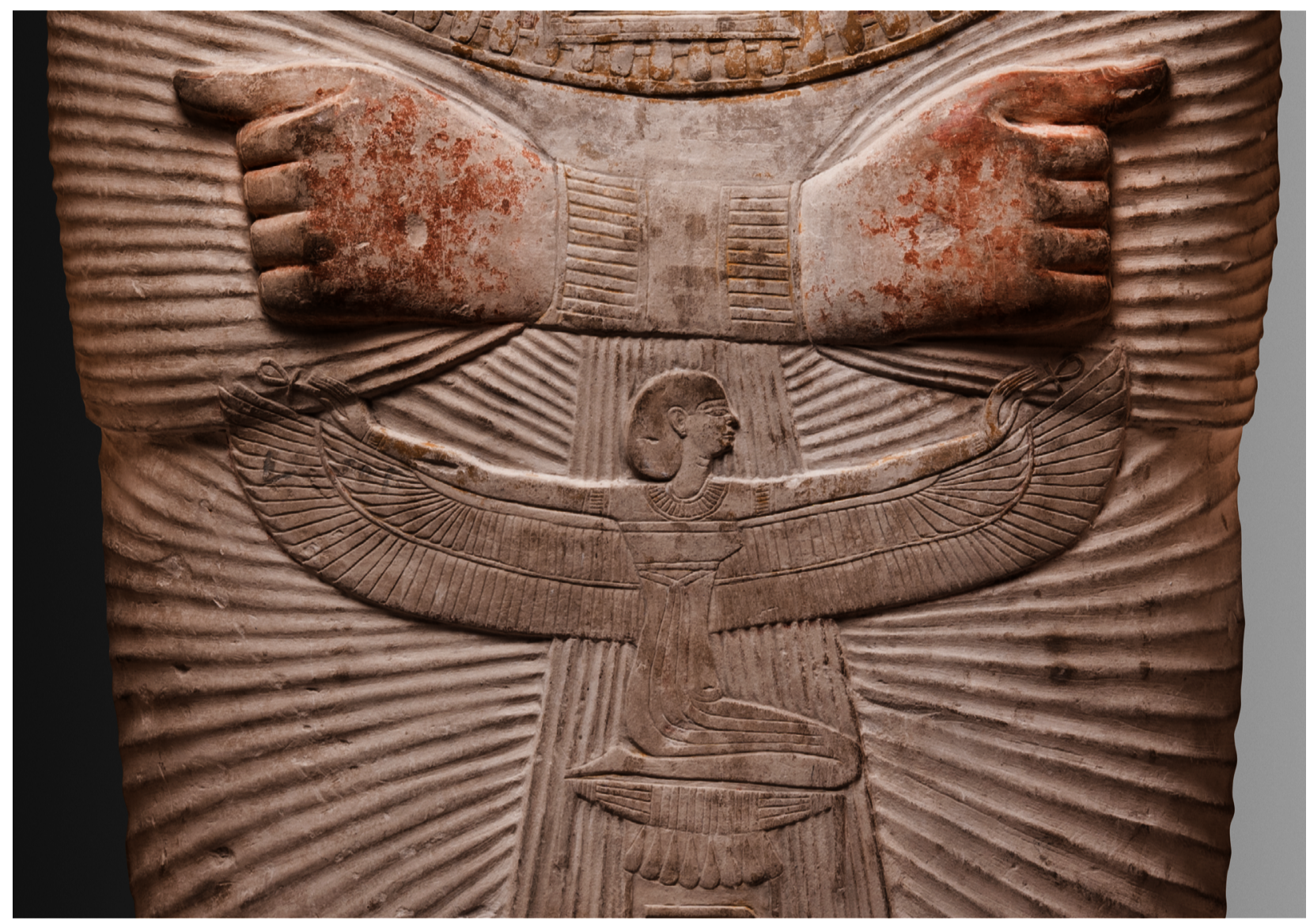

Fig. 21: Coffin lid Turin Cat. 2208, detail. Photo: Nicola Dell'Aquila and Federico Taverni/Museo Egizio.

the deceased in coffin lid Turin Cat. 2208 (Fig. 21). ${ }^{88}$ Investigating the meaning of such devices in the general context of the evolution of the aesthetic and cultural sensibilities underpinning New Kingdom formal art falls outside the scope of the present article. It is enough here to remark the occurrence of this peculiarity in the Turin statue of Hel, which stands as an at once typical and idiosyncratic expression - in its style, iconography, and inscriptions - of these sensibilities, as well as of the sophistication of the elites of the time, and of the artists in their employ.

\section{Notes}

${ }^{1}$ Fassone and Facchetti, Bellezza, 2019, p. 5; Connor, Le statue, 2016, p. 63, fig. 63; Poole, in Museo Egizio, 2015, p. 96, fig. 95; Vassilika, Masterpieces, 2009, p. 89; Vassilika, Tesori d'arte, 2006, no. 43; Donadoni, in Donadoni Roveri (ed.), Civiltà degli Egizi: Le arti della celebrazione, 1989, p. 166, fig. 243 on p. 157; Farina, Museo di antichità, $1938^{2}$, p. 11.

${ }^{2}$ References given in the course of this article.

${ }^{3}$ I gratefully acknowledge feedback and/or information from Anne Herzberg-Beiersdorf, Daniela Picchi, Guillemette Andreu, Jana Jones, Matilde Borla, Lara Weiss, and Dietrich Raue, technical assistance and counsel from Sara Aicardi, and textual suggestions by Gordon Poole. I am particularly indebted to René van Walsem and Simon Connor for inspiration and for their comments on the first and the final draft, respectively, as well as to Philippe Collombert for crucial ep-

igraphic insight. Finally, I am pleased to acknowledge careful reading and valuable input and corrections, and helpful general advice, by the two anonymous reviewers of this article, respectively.

${ }^{4}$ Fabretti et al., Regio museo di Torino, I, 1882 and II, 1888; our statue appears in the second volume, p. 333, no. 7352 .

${ }^{5}$ For an overview of the history and composition of the Vecchio Fondo, see Curto, Storia del Museo Egizio di Torino, $1990^{3}$, pp. 41-50 and 87-104.

${ }^{6}$ Ministero della pubblica istruzione, Documenti inediti, III, 1880, p. 288.

${ }^{7}$ Petrie MSS 3.1.120, Griffith Institute Archive's Online Catalogue, http://archive.griffith.ox.ac.uk/petrie-3-1 -120 .

${ }^{8}$ The year is handwritten on a typewritten report on work done on the statue by the art restoration company Barbara \& Giorgio Gioia, s.n.c., Turin, from 
the archives of the Soprintendenza Archeologia del Piemonte (the local state antiquities office). The restoration also involved the removal of some modern stucco repairs and the use of Paraloid B 72 (diluted to $3 \%$ ) to consolidate the more abraded parts and protect the whole surface.

${ }^{9}$ By Museo Egizio assistant collection manager Sara Aicardi.

${ }^{10}$ DZA 27.857.950 (cf. Wb III, 286.11), online at TLA, http://aaew.bbaw.de/tla/servlet/TlaLogin. My attempt to identify the author in the TLA contributors' handwriting page was unfruitful (https://aaew.bbaw.de/ archive/das-digitalisierte-zettelarchiv/album/handschrift-dza).

${ }^{11}$ Pernigotti, La statuaria, 1980, pp. 52-54, pls. 68-69; Hema, Group Statues, 2005, no. 101, I, pp. 26-27, II, pp. 215-18.

${ }^{12}$ Schiaparelli, Museo Archeologico di Firenze, 1887, no. 1513, pp. 212-15.

${ }^{13}$ Urk. IV, 1805,7 (references to cryptographic $p r$ in the New Kingdom courtesy of Philippe Collombert and René van Walsem).

${ }^{14}$ Drioton, $R d E 1$ (1933), p. 5.

${ }^{15}$ PM VIII.4, 2012, no. 803-050-281, pp. 149-50.

${ }^{16}$ Drioton, $R d E 1$ (1933), pp. 23-34, see esp. pp. 23, 26, and 29.

${ }^{17}$ Legrain, Statues, II, 1909, p. 53, d.7.

${ }^{18}$ Gaballa, The Memphite Tomb-Chapel of Mose, 1977, pl. 24.

${ }^{19}$ I owe the identification of this sign, and the consequent reading of the word as $d h n$, to Philippe Collombert. The author of the above-cited Zettel did not recognize the poorly preserved glyph and hence mistook the rest of the word to read hnw.t, "female musician"; as a consequence, the locus is erroneously cited as an instance of the latter in Wb. III, 286,11 (cf. the Belegstelle for this item).

${ }^{20}$ LGG IV, p. 167 (two occurrences).

${ }^{21}$ Unless one chooses to interpret the strokes - as suggested to me, again, by Philippe Collombert - as writings of the first person suffix pronoun $=i$ : "(I) make music for (my) mistress, I play rhythm in her place, I play the sistrum for (my) Lady, (I) pacify her every day". This rendering, however, assumes that the suffixes are written out in two cases and implicit in another four. An example of the stroke as a writing of the suffix pronoun $=i \mathrm{ca} n$ be found on a doorjamb of Ptahmose, high priest of Ptah, UC 14477 (Nineteenth Dynasty): Stewart, Egyptian Stelae, 1976, pl. 43.2, p. 53, with correction by Caminos, JEA 64 (1978), p. 157; references courtesy of Philippe Collombert.

${ }^{22}$ Cf. Junge, Late Egyptian Grammar, 2005, p. 77.

${ }^{23}$ Bryan, in Kozloff and Bryan (eds.), Egypt's Dazzling Sun, 1992, no. 43, pp. 249-50 (pp. 210-11 in the French version, Aménophis III: le pharaon-soleil, 1993).

${ }^{24}$ The analytical, feature-by-feature approach adopted here was inspired by René van Walsem's study of the statue of Meryneith and Anuy, in Raven and van Walsem, The Tomb of Meryneith, 2014, pp. 187-217.

${ }^{25}$ Tefnin, CdE 46/91 (1971), pp. 39-41; Van Walsem, in Raven and van Walsem, The Tomb of Meryneith, 2014, p. 209.
${ }^{26}$ AST 2 and 3, Martin, The Tomb of Maya and Meryt, I, 2012, respectively no. 23, p. 28, pls. 119-23, and no. 17 , pp. $24-26$, pls. $124-27$.

${ }^{27}$ Hannover, Kestner-Museum, 1935.200.106: Nofret - Die Schöne [II], 1985, no. 117, pp. 52-53, and Eggebrecht, Ägyptens Aufstieg zur Weltmacht, 1987, no. 9, p. 110.

${ }^{28}$ http://www.unesco.org/culture/museum-fordialogue/item/en/73/bust-from-a-female-statuette.

${ }^{29}$ See the detailed discussion of this feature by van Walsem, in Raven and van Walsem, The Tomb of Meryneith, 2014, pp. 204-07, and the parallels listed on p. 205, n. 146, with further bibliography; additional examples include the statues of Ney and Mutnofret, Munich, Gl. W.A.F. 25 (Schoske and Wildung, Das Münchner Buch, 2013, pp. 120-21), Sibe and Weretkhenit, Munich, Gl. W.A.F. 33 (Staatliche Sammlung Ägyptischer Kunst, 1972, no. 71, pp. 80-81, pl. 43); Hori and Nefertari, Louvre A 68 (Seipel, Gott - Mensch - Pharao, 1992, no. 139, pp. 350-51); Nakhtmin and Tiye, CG 622 (Borchardt, Statuen, II, 1925, pp. 167-69, pl. 113); Pendua and Nefertari, Turin S. 6127 (Borla, in Andreu and Donadoni Roveri [eds.], Gli artisti del Faraone, no. 58, p. 114); and several shabtis, including National Museum of Ireland 1954:161, http://www.globalegyptianmuseum.org/ record.aspx?id=2694, The Israel Museum, accession no. 97.063.0165, https://www.imj.org.il/en/collections/309200, and one in the Meux collection, Budge, Some Account of the Collection... of Lady Meux, 18962, p. 160, pl. 22.1.

${ }^{30}$ Van Walsem, in Raven and Walsem (eds.), The Tomb of Meryneith, 2014, p. 205, n. 147.

${ }^{31}$ BM EA 37887: BM collection online, https://www. britishmuseum.org/collection/object/Y_EA37887; Hofmann, in [Petersen and Kehrer] (eds.), Ramses: Göttlicher Herrscher, pp. 140-41 (see also p. 204, no. 84).

${ }^{32}$ Russmann, in Russmann (ed.), Eternal Egypt, 2001, no. 94 , pp. $186-87$.

${ }^{33}$ Seipel, Gott - Mensch - Pharao, no. 82, pp. 238-39.

${ }^{34} \mathrm{BM}$ EA 48001, BM collection online, https://www.britishmuseum.org/collection/object/Y_EA48001_1.

${ }^{35}$ Respectively, by Van Walsem, in Raven and Walsem (eds.), The Tomb of Meryneith, 2014, p. 205, n. 147, and Strudwick, Masterpieces of Ancient Egypt, 2006, pp. $214-15$.

${ }^{36}$ Polz, in Bayer-Niemeyer et al., Ägyptische Bildwerke, III, 1993, no. 70, pp. 302-23, esp. pp. 321-22; see also Raedler, in [Petersen and Kehrer] (eds.), Ramses: Göttlicher Herrscher, 2016, pp. 148-49 (see also p. 206, no. 82).

${ }^{37}$ Dyad of Mutnofret and Ney (Nineteenth Dynasty) in Munich, Gl. W.A.F. 25, Die Ägyptische Sammlung des Bayerischen Staates, 1966, showcase 40 (no page nos.); Schoske and Wildung, Das Münchner Buch, 2013, pp. 120-21.

${ }^{38}$ Berlin ÄM 13460: Hardekopf, in [Petersen and Kehrer] (eds.), Ramses: Göttlicher Herrscher, 2016, pp. 120-21 (see also p. 126, no. 66); Staatliche Museen zu Berlin, SMB-digital, http://www.smb-digital.de/e MuseumPlus?service $=$ Externalinterface $\&$ module $=$ collection \&objectId=606550\&viewType $=$ detailView . 
${ }^{39}$ See van Walsem's detailed overview of this feature in Raven and van Walsem (eds.), The Tomb of Meryneith, 2005, pp. 212-13.

${ }^{40}$ Vandier, Manuel, III.1, p. 439, n. 6.

${ }^{41}$ The earliest examples known to me are, for menat holders, CG 588 (see below, note 44), for sistrophores, Louvre A. 62, Eggebrecht, Ägyptens Aufstieg zur Weltmacht, pp. 256-58, no. 184.

${ }^{42}$ The examples, in text and image, are numerous; for the New Kingdom, one could mention the tombs of Kheruef, TT192: The Epigraphic Survey, The Tomb of Kheruef, 1980, https://oi.uchicago.edu/pdf/oip102. pdf, pl. 57. See also Fig. 15 in the present article.

${ }^{43}$ Including the statues of Tuy in the Louvre, E 10655, and of Nebuemwesekhet in Brussels, MRAH, E. 6356, both from the time of Amenhotep III (Tefnin, $C d E$ 46/91 [1971], pp. 35-49 and 45-49, respectively), statue CG 779B of the wife of Nakhtmin, from the time of Ay or Sety I, and a statue of a Ramesside queen, CG 600.

${ }^{44}$ CG 588, Borchardt, Statuen, II, 1925, pp. 143-44, pl. 106; Hema, Group Statues, 2005, no. 49, I, pp. 110-11, II, p. 87; dated probably to the reign of Amenhotep II by Vandier, Manuel, III.1, 1958, p. 502(G). Borchardt and Vandier identify the menat, respectively, as a "Schmuckgegenstand" (p. 143) and a "fleur" (p. 443, n. 5); for Hema, she is "holding something" (I, p. 111).

${ }^{45}$ AST 2: Martin, The Tomb of Maya and Meryt, 2012, no. 23, p. 28, pls. 119-23.

${ }^{46}$ Bierbrier, Hieroglyphic Texts from Egyptian Stelae, Etc., Part 12., pls. 96-97, pp. 25-26, and BM collection online, https://www.britishmuseum.org/collection/ object/Y_EA484.

${ }^{47}$ Baltimore, Walters Art Gallery, 22.106 and Tokyo, Matsuoka Museum, 568: Steindorff, JWAG 5 (1942), pp. 8-17, Steindorff, Catalogue of the Egyptian Sculpture, no. 106, p. 41, pls. 21 and 112; Capel and Markoe (eds.), Mistress of the House, 1996, no. 35a, pp. 96-98; and Schulz, in Seidel and Schulz, Egyptian Art, 2009, pp. 92-93, which cites Turin Cat. 7352 as a parallel (n. 5 on p. 93). See also Staring, BIFAO 114 (2014), pp. 464-65, nn. 69-70, 72-73; Staring, BACE 25 (2014), pp. 131-33, figs. 6-7 on p. 123. First recognized as belonging to Ptahmose's wife and paired with the Leiden statues of Ptahmose, AST 7 and AST

8, to my knowledge, in PM III2, pp. 714-15; cf. Malek, RdE 38 (1987), pp. 119-20, and KRI VII, p. 113. See also the dyad of the two from Saqqara, Cairo JE 41532, Quibell, Excavations at Saqqara (1908-9, 1909-10), p. 146, pl. LXXXVI.1,2, https://archive.org/details/ Cu31924028671273; PM III2, p. 714; KRI III, p. 180.

${ }^{48}$ For a similar half-round rendering, cf. the statue of Sennuwy, Boston, MFA, 14.720 (Middle Kingdom): https://www.mfa.org/collections/object/statue-oflady-sennuwy-141967.

${ }^{49}$ Van Walsem, in Raven and van Walsem, The Tomb of Meryneith, 2014, p. 214.

${ }^{50}$ Hema, Group Statues, 2005, no. 124, I, pp. 268-70, II, pp. 273-75; Andreu (ed.), Les artistes de Pharaon, 2002, no. 65, pp. 122-23; Priese, Ägyptisches Museum, 1991, no. 276, pp. 117 and 276; SMB-digital, http://www.
smb-digital.de/eMuseumPlus?service=External Interface $\&$ module $=$ collection $\&$ objectId $=606549 \&$ viewType $=$ detailView.

${ }^{51}$ Hema, Group Statues, 2005, no. 116, I, p. 251-52, II, pp. 244-46; Seipel, Ägypten, 1989, I, no. 459, pp. 284-85.

${ }^{52}$ Van Walsem, in Raven and van Walsem, The Tomb of Meryneith, 2014, pp. 214-15.

${ }^{53} \mathrm{Cf}$. van Walsem, in Raven and van Walsem, The Tomb of Meryneith, 2014, p. 215, nn. 269-70, where the Turin statue is listed among other statues displaying this feature, namely, the above-mentioned dyads Berlin 6910 and Louvre E 3516, and dyad CG 635.

${ }^{54}$ Cairo, JE 37484: Nofret - Die Schöne [I], 1984, no. 25, pp. 62-63.

${ }^{55}$ One would expect the stem to be green, as it is in nature, but red lotus-flower stems are actually quite common in Egyptian art; compare, for example, stelae BM EA 65355, 8497, 276, 1248, 8485: HTBM, X, pp. 31-32 and 34-36 (for a color photograph of stela EA 8497, see BM collection online, https://www.british museum.org/research/collection_online/collection_ object_details/collection_image_gallery.aspx?assetId $=394668001 \&$ objectId=176227\&partId=1). A lotus flower with a red stem and green bud is held by the daughter of Pawer and Mut depicted on the left side of the seat of their dyad, Turin Cat. 3057; Hema, Group Statues, 2005, no. 40, II, pl. 40b (photo in black and white).

${ }^{56}$ Schoske and Wildung, Das Münchner Buch, 2013, pp. 120-21, and Hema, Group Statues, 2005, no. 132, I, pp. 289-91, II, p. 299 (photo in black and white); another statue of the same general period with preserved colors is BM EA 2302, https://www.british museum.org/research/collection_online/collection_ object_details.aspx?objectId=120254\&partId=1\& searchText $=2302 \&$ page $=1$.

${ }^{57}$ Davies, Who's Who, 1999, p. 76, n. 5; for literature on the statue, see above, note 50 .

${ }^{58}$ Obsomer, Ramsès II, 2012, pp. 273-74, with literature.

${ }^{59}$ Literature given above, note 47.

${ }^{60}$ van Dijk, GM 113 (1989), pp. 47-54, p. 53; cf. Malek, $R d E 38$ (1987), pp. 134-35, and Greco, in Picchi et al. (eds.) Aegyptiaca et Coptica: studi in onore di Sergio Pernigotti, 2011, pp. 196-97.

${ }^{61}$ Berlandini, BIFAO 82 (1982), pp. 85-103, p. 102, no. 5, cf. p. 85 , no. 1 .

${ }^{62}$ The similarity of Inehy's statue to Meryt's is stressed by Steindorff, JWAG 5 (1942), pp. 9-13; [Capel and/ or Markoe] even postulate a direct filiation of the former from the latter, which, they argue, must have been a prestigious model, and as such "unabashedly copied by other upperclass women": see catalogue entry (uncredited) in Capel and Markoe (eds.), Mistress of the House, 1996, no. 35a, pp. 96-97. In a broader perspective, it is the tomb of Ptahmose as a whole that is evidently patterned, in several significant aspects - including its plan and architecture, several relief scenes, and statues of the deceased and his wife Inehy - after the tomb of Maya, as shown by Raven, in Kubisch and Rummel (eds.), The Ramesside Period, 2018, pp. 239-43. 
${ }^{63}$ Ascribed to Deir el-Medina by Donadoni, in Donadoni Roveri (ed.), Civiltà degli Egizi: Le arti della celebrazione, 1989, pp. 165-66. This attribution apparently went a long way back, as it is already present in the original caption in Petrie's photographic album to the above-mentioned 1893 photo of Turin Cat. 7352: "Seated statue of Hunen (Hunuro?) (woman), Dyn. XIX, from Deir el-Medina” (Petrie MSS 3.1.120, http:// archive.griffith.ox.ac.uk/petrie-3-1-120). The provenance was later corrected to Saqqara by the present writer, in Museo Egizio, 2015, p. 96.

${ }^{64}$ Cat. 3225, 3226, 3227, 3228, Cat. 6227; Lilyquist, $M M J$ 23 (1988), pp. 5-68., esp. pp 10-13; for Cat. 3226, see Fassone, in Giovetti and Picchi (eds.), Egitto. Splendore millenario, no. V.4, pp. 238 and 525-26, with further literature.

${ }^{65}$ Ministero della pubblica istruzione, Documenti inediti, III, 1880, p. 288, no. *96.

${ }^{66}$ Ministero della pubblica istruzione, Documenti inediti, III, 1880, p. 274.

${ }^{67}$ Lilyquist, MMJ 23 (1988), p. 37.

${ }^{68} \mathrm{PN}, \mathrm{I}, 245.7$. The former appears to be a mere graphic variant of the latter, with the double yod at the end possibly being left out mainly due to space constraints; there indeed does not seem to be space for such an ending in the lacuna at the end of either of the two texts on the Turin statue. The group $11_{1}$ and its variants are commonly used to transcribe the sound "l" (see, for example, Junge, Late Egyptian Grammar, p. 42).

${ }^{69}$ Besides those discussed more in detail below, they include Serapeum stelae Louvre IM 6153 and IM 5269 $\mathrm{M}$, both Ramesside, name written as Hely, Malinine et al., Catalogue des stèles du Sérapéum, I, 1968, no. 8 (pp. 8-9, pl.4) and no. 9 (pp. 9-10, pl. 3), Charron and Barbotin (eds.), Savoir et pouvoir, nos. 78-79, pp. 142-45; box fragment from the tomb of Maya and Meryt, late Eighteenth to Nineteenth Dynasty (Hely), Raven, The Tomb of Maya and Meryt, II, 2001, Cat. 125, p. 36, pls. 18 and 38; six faience shabtis, Ramesside, from the tomb of Iurudef, Raven, The Tomb of Iurudef, 1991, Cat. 52a-f, p. 32 and 42, pls. 9c, 41, 45 (Hel). My search for women named Hel(y) in the Memphite area was greatly facilitated by a list kindly extracted for me by Anne Herzberg-Beiersdorf from her Prosopographia Memphitica database (to be made available for consultation in the near future at the following stable DOI: 10.5281/zenodo.2547538).

${ }^{70}$ On her temple, see Mahmud, A New Temple for Hathor, 1978, and Pasquali, Topographie cultuelle de Memphis 1, Montpellier 2011, pp. 83-86, http://www.enimegyptologie.fr/cahiers/4/Pasquali_CENIM4.pdf.

${ }^{71}$ Maystre, Les grandes prêtres de Ptah, 1992, pp. 143-45.

${ }^{72}$ BM EA 183: James, HTBM IX, 1970, pl. 15, pp. 19-20; https://www.britishmuseum.org/collection/object/Y_ EA183. The stela also includes Pahemnetjer's son, the vizier (Pa-)Rahotep, among the honored individuals, and this Hely might thus well be his wife of this name, as James suggests. In this case, however, it would be unlikely that she could be the owner of Turin Cat. 7352 , since she was buried with her husband in Sedment, where she bore the title of "chief of the harem of
Herishef" - although (Pa-)Rahotep may have had a votive chapel in Saqqara: Raue, in Guksch and Polz (eds.), Stationen, 1998, pp. 349-50, and Raven et al., The Memphite Tomb of Horemheb, V, 2011, pp. 58-59, no. 28; for further literature on (Pa-)Rahotep, see Staring, JEA 102 (2016), p. 159, n. 63. A shabti and a box lid, dated to "D. 18-19", of a Hely bearing the title of chantress of the Lady of the Southern Sycamore, unpublished as far as I know, were found in the EES-Leiden excavations carried out in the New Kingdom cemetery south of the Unas Causeway in Saqqara between 1982 and 1989: van Dijk, in van Dijk and Schulman (eds.), The New Kingdom Memphis Newsletter 2 (1989), p. 12, http://www.jacobusvandijk.nl/docs/NKMN_2.pdf.

${ }^{73}$ Raue, in Grossmann, MDAIK 65 (2009), pp. 72-74, pl. 19, with a proposed date, based on style, in the later Nineteenth Dynasty.

${ }^{74}$ Zivie, The Lost Tombs of Saqqara, 2007, p. 140; on the tomb and its owner, see also Zivie, BMSAES 6 (2006), pp. 68-78 (https://webarchive.nationalarchives.gov. uk/20190801120912/https://www.britishmuseum. org/pdf/6f\%20Le\%20messager\%20royal.pdf); Zivie, CRAIBL 145/1 (2001), pp. 693-710, https://doi.org/10.3406/crai.2001.16293.

${ }^{75}$ While a number of pleated garments dating from the Early Dynastic period to the Middle Kingdom (see for example Jones, JEA 100 [2014], pp. 209-31) are preserved, apparently none of the surviving textiles from the New Kingdom show this feature (although a couple of unconfirmed specimens were seen by Jana Jones in Cairo; personal communication). It has been suggested that this kind of representation is actually a conventional rendering, not of pleats, but of the folds formed by the garments when draped around the body: Pedrini, GM 87 (1985), p. 66, and Pedrini, L'arte dell'apparire, 2016, p. 105. The fact that in preserved pleated dresses the pleats run horizontally across the body, whereas the "pleats" in New Kingdom statuary appear exactly where one would expect a dress to form folds (e.g., vertically down the legs and obliquely along the part of the female dress wrapped across the breast) speaks in favor of this thesis (a suggestion I owe to Matilde Borla, who first drew my attention to this issue). For a different view, see, for example, the contributions of Johnstone and Richards, in Graves-Brown (ed.), Egyptology in the Present, 2015, esp. pp. 86-87 and 141, respectively.

${ }^{76}$ Pernigotti, La statuaria, 1980, pp. 52-54, pls. 68-69; Hema, Group Statues, 2005, no. 101, I, pp. 226-27, II, pp. 215-18.

${ }^{77}$ Staatliche Sammlung $\ddot{g} g$ ptischer Kunst, 1972, no. 71, pp. 80-81, pl. 43.

${ }^{78} \mathrm{~A}$ consideration I owe to one of my anonymous reviewers.

${ }^{79}$ See, for example, shabtis Naples 397 and Darmstadt A. 82:1: Poole, in Cantilena and Rubino (eds.), La collezione egiziana, 1989, no. 19.1, p. 175, fig. 19, and Schlick-Nolte and von Droste zu Hülshoff, Uschebtis, I, pp. 1-3.

${ }^{80}$ Literature and information at note 47 above.

${ }^{81}$ Martin, The Tomb of Maya and Meryt, I, 2012, pp. 27-28. 
${ }^{82}$ In the case of the statues of Horemheb's tomb in Saqqara, their unfinished state may depend on his rise to the throne before his non-royal burial was completed: van Walsem and Raven, in Raven et al., The Memphite Tomb of Horemheb, V, 2011, pp. 379-80.

${ }^{83}$ In this regard, also compare the way the Leiden Meryt's left wig lappet projects below the forearm with the more restrained treatment of this detail in Inehy's statues; this difference is due to the fact that in the former sculpture the left upper arm is detached from the body, and the forearm hence intersects the wig higher up.

${ }^{84}$ CG 628, Borchardt, Statuen II, 1925, pp. 175-76, pl. 115 (Eighteenth to Nineteenth Dynasty); cf. van Walsem, in Raven and van Walsem (eds.), The Tomb of Meryneith, 2014, p. 201, n. 116.

${ }^{85}$ Hema, Group Statues, 2005, no. 126, I, pp. 273-76, II, pp. 280-81; Capel and Markoe, Mistress of the House, 1996, no. 93, pp. 172-74; The Met Collection, https:// www.metmuseum.org/art/collection/search/544740.

${ }^{86}$ van Walsem and Raven, in Raven et al., The Memphite Tomb of Horemheb, V, 2011, pp. 375-78, with figs. on p. 379; cf. statue Bologna KS 1817, Pernigotti, La statuaria, cat. 9, pp. 39-40, pls. 44-45, and van Walsem and Raven, in Raven et al., The Memphite Tomb of Horemheb, V, n. 514 on p. 377.

${ }^{87}$ In a manner different from, but not unrelated to, what Roland Barthes dubbed "l'effet de réel”, which has been defined as follows: "The small details of person, place, and action that, while contributing little or nothing to the narrative, give the story its atmosphere, making it feel real" (Buchanan, A Dictionary of Critical Theory, 2010, p. 401, s.v. "reality-effect (effet de réel)"; cf. Roland Barthes, Communications 11/1 [1968], pp. 84-89, https://doi.org/10.3406/ comm.1968.1158).

${ }^{88}$ Hofmann, in [Petersen and Kehrer] (eds.), Ramses, 2016, no. 70, p. 119-200.

\section{Bibliography}

Andreu, Guillemette (ed.) Les artistes de Pharaon: Deir el-Médineh et la Vallée des Rois. Paris, musée du Louvre, 15 avril-5 août 2002, Bruxelles, Musées royaux d'art et d'histoire, 11 septembre 2002-12 janvier 2003, Turin, Fondation Bricherasio, 11 février-18 mai 2003, Paris and Turnhout 2002.

Barbara \& Giorgio Gioia, s.n.c., "Relazione tecnica sullo stato di conservazione e intervento di restauro. Documentazione fotografica", typewritten report, archives of the Soprintendenza Archeologia del Piemonte, 1989.

Barthes, Roland, "L’effet de réel." Communications 11/1 (1968), pp. 84-89. https://doi.org/10.3406/ comm.1968.1158.

Berlandini, Jocelyne, "Varia memphitica V: monuments de la chapelle funéraire du gouverneur Ptahmès", BIFAO 82 (1982), pp. 85-103.

Borchardt, Ludwig, Statuen und Statuetten von Königen und Privatleuten im Museum von Kairo, Nr. 1-1294, II: Text und Tafeln zu Nr. 381-653 (Catalogue général des antiquités égyptiennes du Musée du Caire), Berlin 1925.

Borla, Matilde, "Statua dei coniugi Pendua e Nefertari", in Guillemette Andreu and Anna Maria Donadoni Roveri (eds.), Gli artisti del Faraone: Deir el-Medina e le Valli dei Re e delle Regine, Milano 2003.

Bryan, Betsy M., “Anen, second prophète d'Amon”, in: Arielle P. Kozloff and Betsy M. Bryan, Aménophis III: le Pharaon-Soleil, Paris 1993, pp. 210-11.

Bryan, Betsy M., "Statue of Anen, Second Prophet of Amen”, in: Arielle P. Kozloff and Betsy M. Bryan, Egypt's Dazzling Sun: Amenhotep III and His World, Cleveland 1992, pp. 249-50.

Buchanan, Ian, A Dictionary of Critical Theory, Oxford 2010. Budge, Ernest A.W., Some Account of the Collection of Egyptian Antiquities in the Possession of Lady Meux, of Theobald's Park, Waltham Cross, London, $1896^{2}$.

Caminos, Ricardo A., review of H.M. Stewart, Egyptian Stelae, Reliefs and Paintings from the Petrie Collection, Part One: The New Kingdom, Warminster 1976, in JEA 64 (1978), pp. 151-57.

Capel, Anne K., and Glenn E. Markoe (eds.), Mistress of the House, Mistress of Heaven: Women in Ancient Egypt, New York 1996.

Connor, Simon, Le statue del Museo Egizio, Torino 2016. Curto, Silvio, Storia del Museo Egizio di Torino, Turin $1990^{3}$. Davies, Benedict G., Who's Who at Deir el-Medina: A Prosopographic Study of the Royal Workmen's Community (EU 13), Leiden 1999.

Die Ägyptische Sammlung des Bayerischen Staates: Ausstellung in den Ausstellungsräumen der Staatlichen Graphischen Sammlung München, Meiserstrasse 10, Erdgeschoss vom 21. Juli bis 5. Oktober 1966, München 1966.

Dijk, Jacobus van, “A Preliminary List of New Kingdom Names and Titles from the EES-Leiden Excavations at Saqqâra (1982-1989)", in Jacobus van Dijk and Adam R. Schulman (eds.), The New Kingdom Memphis Newsletter 2 (September 1989), pp. 8-12. http://www.jacobus vandijk.nl/docs/NKMN_2.pdf.

Dijk, Jacobus van, "Two Blocks from the Tomb of Ptahmose”, GM 113 (1989), pp. 47-54.

Donadoni, Sergio, "L'immagine e la forma: l'esperienza della scultura”, in: Anna Maria Donadoni Roveri (ed.), Civiltà degli Egizi, III: Le arti della celebrazione, pp. 98-185, Milano 1989.

Drioton, Étienne, “Essai sur la cryptographie privée de la fin de la XVIIIe dynastie”, RdE 1 (1933), pp. 1-50.

Eggebrecht, Arne, Ägyptens Aufstieg zur Weltmacht, Mainz 1987.

Epigraphic Survey, The, The Tomb of Kheruef: Theban Tomb 192 (OIP 102), Chicago 1980. https://oi.uchicago.edu/ pdf/oip102.pdf.

Fabretti, Ariodante, Francesco Rossi, and Ridolfo Vittorio Lanzone, Regio museo di Torino. Antichità egizie (Catalogo generale dei musei di antichità e degli oggetti d'arte raccolti nelle gallerie e biblioteche del regno, 1. Piemonte), II, Torino 1888.

Farina, Giulio, Il R. museo di antichità di Torino. Sezione egizia (Itinerari dei musei e monumenti d'Italia 7), $1938^{2}$.

Fassone, Alessia, in: Paola Giovetti and Daniela Picchi (eds.), Egitto. Splendore millenario. La collezione di Leiden a Bologna, Milano 2016.

Fassone, Alessia, and Federica Facchetti, Bellezza nell'antico Egitto, Modena 2019.

Gaballa, G.A., The Memphite Tomb-Chapel of Mose, Warminster 1977. 
Greco, Christian, “The Lost Tomb of Ptahmes”, in: Paola Buzi, Daniela Picchi, and Marco Zecchi (eds.), Aegyptiaca et Coptica: studi in onore di Sergio Pernigotti, Oxford 2011, pp. 195-204.

Hardekopf, "Ein Kopf des Chaemwese (?)", in: [Lars Petersen and Nicole Kehrer] (eds.), Ramses: Göttlicher Herrscher Am Nil, Petersberg 2016, pp. 120-21.

Hema, Rehab Assem, Group Statues of Private Individuals in the New Kingdom, I-II (BAR-IS 1413), Oxford 2005.

Hofmann, Eva, “Eine edle Dame mit Sistrum”, in: [Lars Petersen and Nicole Kehrer] (eds.) Ramses: Göttlicher Herrscher Am Nil, Petersberg 2016, pp. 140-41.

HTBM, IX = James, T.G.H., Hieroglyphic Texts from Egyptian Stelae, Etc., IX, London 1970.

HTBM, X = Bierbrier, M.L., Hieroglyphic Texts from Egyptian Stelae, Etc., X, London 1982.

HTBM, XII = Bierbrier, M.L., Hieroglyphic Texts from Egyptian Stelae, Etc., XII, London 1993.

Johnstone, Janet M., "Practical Dressmaking for Ancient Egyptians - Making and Pleating Replica Ancient Egyptian Clothing”, in: Graves-Brown, Carolyn (ed.), Egyptology in the Present: Experiential and Experimental Methods in Archaeology, Swansea 2015.

Jones, Jana, "The Enigma of the Pleated Dress: New Insights from Early Dynastic Helwan Reliefs”, JEA 100 (2014), pp. 209-31.

Junge, Friedrich, Late Egyptian Grammar: An Introduction, Oxford 2005.

Legrain, Georges, Statues et statuettes de rois et de particuliers (Catalogue général des antiquités égyptiennes du musée du Caire, Nos. 42139-42191), Le Caire 1909.

$L G G=$ Christian Leitz (ed.), Lexikon der ägyptischen Götter und Götterbezeichnungen (OLA 100-116; 129), Leuven 2002-2003.

Lilyquist, Christine, “The Gold Bowl Naming General Djehuty: A Study of Objects and Early Egyptology", MMJ 23 (1988), pp. 5-68.

Mahmud, Abdulla el-Sayed, A New Temple for Hathor at Memphis (Egyptology Today 1), Warminster 1978.

Malek, Jaromir, “The Saqqara Statue of Ptahmose”, RdE 38 (1987), pp. 117-37.

Malinine, M., G. Posener, and J. Vercoutter, Catalogue des stèles du Sérapéum de Memphis, I, Paris 1968.

Martin, Geoffrey Thorndike, The Tomb of Maya and Meryt, I: The Reliefs, Inscriptions and Commentary, London 2012.

Maystre, Charles, Les grandes prêtres de Ptah de Memphis (OBO 113), Freiburg (Schweiz) and Göttingen 1992.

Meulenaere, H. de., "Deux vizirs de Ramsès II" CdE 41/82 (1966), pp. 223-32.

Ministero della pubblica istruzione, Documenti inediti per servire alla storia dei musei d'Italia, III, Torino 1880.

Nofret - die Schöne [I] = Nofret - Die Schöne: die Frau im Alten Ägypten. Haus der Kunst München, 15. Dezember 1984 - 10. Februar 1985; Ägyptisches Museum Berlin, 23. März 1985 2. Juni 1985; Roemer- und Pelizaeus-Museum Hildesheim, 15. Juli 1985 - 4. November 1985, Mainz 1984.

Nofret - die Schöne [II] = Nofret - Die Schöne: die Frau im Alten Ägypten: „Wahrheit“ und Wirklichkeit“. Roemer- und Pelizaeus-Museum Hildesheim, 15. Juli 1985 - 4. November 1985, Hildesheim and Mainz 1985.

Obsomer, Claude, Ramsès II (Les grands pharaons), Paris 2012.
Pasquali, Stéphane, Topographie cultuelle de Memphis 1: a-Corpus. Temples et principaux quartiers de la XVIIIe dynastie (Cahiers "Égypte Nilotique et Méditerranéenne" 4), Montpellier 2011. http://www.enim-egyptologie.fr/ cahiers/4/Pasquali_CENIM4.pdf.

Pedrini, Lidia, L'arte dell'apparire nell'Egitto faraonico: Una moda per l'eternità, Genova 2016.

Pedrini, Lidia, “Observations on the Cloak Worn by Private Men During the Old, Middle and New Kingdom”, GM 87 (1985), pp. 63-71.

Pernigotti, Sergio, La statuaria egiziana nel Museo Civico Archeologico di Bologna (Cataloghi Nuova Serie 2), Bologna 1980.

PM VIII.4 = Jaromir Malek, Topographical Bibliography of Ancient Egyptian Hieroglyphic Texts, Statues, Reliefs and Paintings, VIII: Objects of Provenance Not Known. Part 4: Stelae (Dynasty XVIII to the Roman Period), Oxford 2012.

Polz, Daniel, "Sargensemble der Takait", in: Eva Bayer-Niemeyer, Barbara Borg, Günter Burkard, Vera von Droste zu Hülshoff, Detlef Franke, Beatrix Gessler-Löhr, Daniel Polz, Hubert Roeder, Birgit Schlick-Nolte, Stephan Seidlmayer, Karl Joachim Seyfried, and Heinz Josef Thissen, Ägyptische Bildwerke, III: Skulptur, Malerei, Papyri und Särge (Liebieghaus - Museum alter Plastik, Frankfurt am Main, Wissenschaftliche Kataloge), Melsungen 1993, pp. 302-23.

Poole, Federico, "Ushabty della Signora della Casa, Mut(nefret)", in Renata Cantilena and Paola Rubino (eds.), La collezione egiziana del Museo Archeologico Nazionale di Napoli, Napoli 1989.

Poole, Federico, "La materializzazione dello status nel Nuovo Regno”, in: Museo Egizio, Torino 2015, pp. 90-103.

Priese, Karl-Heinz, Ägyptisches Museum: Staatliche Museen zu Berlin. Stiftung Preussischer Kulturbesitz, Mainz 1991.

Quibell, J.E., Excavations at Saqqara (1908-9, 1909-10): The Monastery of Apa Jeremias. Excavations at Saqqara, Cairo 1912. https://archive.org/details/cu31924028671273.

Raedler, Christine, "Der Sargdeckel der Takait”, in: [Lars Petersen and Nicole Kehrer] (eds.), Ramses: Göttlicher Herrscher am Nil, Petersberg 2016, pp. 148-49.

Raedler, Christine, “Die Wesire Ramses' II. - Netzwerke der Macht”, in: Rolf Gundlach and Andrea Klug (eds.), Das ägyptische Konigtum im Spannungsfeld zwischen Innen- und Außenpolitik im 2. Jahrtausend v. Chr. (Königtum, Staat und Gesellschaft früher Hochkulturen 1), Wiesbaden 2004, pp. 277-416.

Raue, Dietrich, “Ein Wesir Ramses’ II.”, in: Heike Guksch and Daniel Polz (eds.), Stationen: Beiträge Zur Kulturgeschichte Ägyptens, Rainer Stadelmann gewidmet, Mainz 1998, pp. 341-51.

Raue, Dietrich, “Zwei als Nischenbänke wiederverwendete Bauteile aus dem Elitefriedhof des Neuen Reiches von Saqqara”, in: Peter Grossmann, "Reinigungsarbeiten im Jeremiaskloster bei Saqqara: fünfter vorläufiger Bericht (Kampagne 1981)”, MDAIK 65 (2009), pp. 72-74.

Raven, Maarten J., "The Saqqara Necropolis in the Ramesside Period: Between Tradition and Innovation" in: Sabine Kubisch and Ute Rummel (eds.), The Ramesside Period in Egypt: Studies into Cultural and Historical Processes of the $19^{\text {th }}$ and $20^{\text {th }}$ Dynasties, Berlin and Boston 2018, pp. 239-48.

Raven, Maarten J., The Tomb of Iurudef: A Memphite Official 
in the Reign of Ramesses II (EES ExcMem 57), Leiden and London 1991.

Raven, Maarten J., The Tomb of Maya and Meryt, II: Objects and Skeletal Remains (EES ExcMem 65), Leiden and London 2001.

Raven, Maarten J., Vincent Verschoor, Marije Vugts, and René van Walsem, The Memphite Tomb of Horemheb, Commander-in-Chief of Tutankhamun, V: The Forecourt and the Area South of the Tomb with Some Notes on the Tomb of Tia (PALMA Eg 6), Turnhout 2011.

Richards, Ann, "Did Ancient Egyptian Textiles Pleat Themselves?”, in: Graves-Brown, Carolyn (ed.), Egyptology in the Present: Experiential and Experimental Methods in Archaeology, Swansea 2015, pp. 139-49.

Russmann, Edna R., Eternal Egypt: Masterworks of Ancient Art from the British Museum, London 2001.

Schiaparelli, Ernesto, Museo Archeologico di Firenze: antichità egizie, Roma 1887.

Schlick Nolte, Birgit, and Vera von Droste zu Hülshoff, Uschebtis, I (CAA Museen der Rhein-Main-Region), Mainz am Rhein 1984.

Schoske, Sylvia, and Dietrich Wildung, Das Münchner Buch der ägyptischen Kunst, München 2013.

Schulz, Regine, and Matthias Seidel, Egyptian Art: The Walters Art Museum, Baltimore and London 2009.

Seipel, Wilfried, Ägypten: Götter, Gräber Und Die Kunst. 4000 Jahre Jenseitsglaube (Kataloge Des OÖ. Landesmuseums, Neue Folge 22), I-II, Linz 1989.

Seipel, Wilfried, Gott - Mensch - Pharao: viertausend Jahre Menschenbild in der Skulptur des alten Ägypten, Wien 1992.

Staring, Nico, "A Relief from the Tomb of the Memphite Mayor Ptahmose in the Nasher Museum of Art at Duke University", BACE 25 (2014), pp. 117-46.

Staring, Nico, “The Tomb of Ptahmose, Mayor of Memphis: Analysis of an Early $19^{\text {th }}$ Dynasty Funerary Monument at Saqqara", BIFAO 114 (2014), pp. 455-518.

Staatliche Sammlung Ägyptischer Kunst: München, Residenz Hofgartenstrasse, München 1972.

Steindorff, George, Catalogue of the Egyptian Sculpture in the Walters Art Gallery, Baltimore 1946.

Steindorff, George, “Two Egyptian Statues of the Ramessid Period", JWAG 5 (1942), pp. 8-17.

Stewart, H.M., Egyptian Stelae, Reliefs and Paintings from the Petrie Collection, Part One: The New Kingdom, Warminster 1976.

Strudwick, Nigel, Masterpieces of Ancient Egypt, London 2006.

Tefnin, Roland, "La date de la statuette de la dame Toui au Louvre”, CdE 46/91 (1971), pp. 35-49.

Vandier, Jacques, Manuel d'archéologie égyptienne, III: Les grandes époques - la statuaire, Paris 1958.

Vassilika, Eleni, Masterpieces of the Museo Egizio in Turin. Official Guide, Torino and Firenze 2009.

Vassilika, Eleni, Tesori d'arte del Museo Egizio, Torino, Londra, Venezia, and New York 2006.

Walsem, René van, and Maarten J. Raven, "New Evidence on Horemheb's Statuary”, in: Maarten J., Raven, Vincent Verschoor, Marije Vugts, and René van Walsem, The Memphite Tomb of Horemheb, Commander-in-Chief of Tutankhamun, V: The Forecourt and the Area South of the Tomb with Some Notes on the Tomb of Tia (PALMA Eg 6), Turnhout 2011, pp. 375-83.

Walsem, René van, “The Double Statue of Meryre and Anuy”, in: Maarten J. Raven and René van Walsem (eds.), The Tomb of Meryneith at Saqqara (PALMA-Eg 10), Turnhout 2014, pp. 187-217.

Zivie, Alain, "Le messager royal egyptien Pirikhnawa", BMSAES 6 (2006), pp. 68-78.

Zivie, Alain-Pierre, The Lost Tombs of Saqqara, n.p. 2007.

Zivie, Alain-Pierre, "Une statue rupestre de la déesse Hathor. Fouilles et découvertes dans le tombeau d'un dignitaire de Ramsès II à Saqqara", CRAIBL 145/1 (2001), pp. 693-710. https://doi.org/10.3406/ crai.2001.16293.

\section{Online sources}

BM collection online $=$ The British Museum. Collection online, https://research.britishmuseum.org/research/collec tion_online/search.aspx.

Griffith Institute Archive's Online Catalogue, http://archive. griffith.ox.ac.uk.

Herzberg, Anne, Prosopographia Memphitica (Version MAJOR) [Data set], Zenodo, 2019, https://doi.org/10.5281/ zenodo. 2547538

Museum of Fine Arts, Boston. Collections, https://collections. mfa.org/collections

SMB-digital $=$ Staatliche Museen $\mathrm{zu}$ Berlin. Preußischer Kulturbesitz, SMB-digital. Online collections database, http://www.smb-digital.de/eMuseumPlus.

The Global Egyptian Museum, http://www.globalegyptian museum.org/.

The Israel Museum, Jerusalem, https://www.imj.org.il/en/ collections/.

The Met Collection, https://www.metmuseum.org/art/col lection.

TLA = Thesaurus Linguae Aegyptiae, Berlin-Brandenburgische Akademie der Wissenschaften, http://aaew.bbaw. de/tla/.

UNESCO, Museums for intercultural dialogue, http://www. unesco.org/culture/museum-for-dialogue/. 